\title{
Performance, Combustion and Emission evaluation of Direct Injection diesel engine fueled with ZnO dispersed waste cooking oil biodiesel
}

\section{Dhanarasu M}

Periyar University

Rameshkumar KA ( $\nabla$ karameshkumar1977@gmail.com )

Periyar University

Maadeswaran P

Periyar University

\section{Research Article}

Keywords: Waste Cooking oil Biodiesel, ZnO Nano particles, Diesel Engine, Performance, Emission

Posted Date: March 18th, 2021

DOI: https://doi.org/10.21203/rs.3.rs-304986/v1

License: (c) (i) This work is licensed under a Creative Commons Attribution 4.0 International License.

Read Full License 


\section{Abstract}

In present scenario, the fast depletion of fossil fuels and energy crises motivated the researchers towards finding an alternative sources for energy. In this work, the performance, combustion and emission of hydrothermally synthesized $\mathrm{ZnO}$ nanoparticles dispersed waste cooking oil biodiesel in single cylinder, four stroke, Direct Injection- Diesel Engine with eddy current dynamometer was investigated. The synthesized ZnO nano particles were characterized by XRD, FTIR, SEM and EDX to find crystallinity, functional groups and surface morphology. Waste cooking oil biodiesel was produced via conventional one step alkali catalyst Trans-esterification process. Test fuels were prepared with dispersion of ZnO nanoparticles in the concentration of $10 \mathrm{ppm}, 20 \mathrm{ppm}$ and $30 \mathrm{ppm}$ with B20 (20\% waste cooking oil biodiesel and $80 \%$ diesel) with the aid of magnetic stirrer and ultra-sonication. The test results exposed that the addition of $\mathrm{ZnO}$ nanoparticles with B20 gave better Performance in terms of BTE and BSFC compared to B20. The addition of $\mathrm{ZnO}$ nano particles with 30ppm concentration was identified as better fuel among all tested fuels in this work. 30ppm addition of $\mathrm{ZnO}$ nano particles with $\mathrm{B} 20$ records $1.78 \%$ increase in BTE and 10.34\% decrease in BSFC. The emission like CO, HC and smoke were $20 \%, 15.4 \%$ and 17.39\% lower than diesel. On the other hand NOx was slightly higher than diesel but lower than B20.

\section{Introduction}

Biodiesel from various feedstock, such as vegetable oils and animal fats, is now the most promising and economically viable alternative fuel for diesel engines. Using biodiesel in a diesel engine causes problems such as greater fuel consumption, low power, increased NOx and cold starting issues.(Hosseini and Wahid 2012) Modified fuel, improved engine design and post-treatment of engine exhaust are the main ways of addressing these problems.(Ahmed et al. 2020) Fuel alteration is an effective way to overcome the problems associated with the use of biodiesel in the engine through a cylinder strategy rather than a high cost of fitting and maintaining exhaust gas treatment. Additives are chemical substances that are introduced with Fuel as a means of adjusting the fuel properties.(Chacko and Jeyaseelan 2020; Tomar and Kumar 2020) Various fuel additives, including antioxidants, oxygenates, metal and metal oxides, cetane enhancers, lubricants and cold flow enhancers, have been widely used as fuel additives(Hosseinzadeh-Bandbafha et al. 2018). The addition of a fuel additive from 20 ppm to 500 ppm is at an affordable level. The greater size of the metal and metal oxide particles causes problems such as sedimentation, conglomeration and non-uniform distribution of the size. As a result, a nano-sized particle that is less than $100 \mathrm{~nm}$ can be used as a diesel or biodiesel additive in an engine without any difficulty(Tomar and Kumar 2020). The addition of nano particles with base fuel tends to complete combustion by the catalytic action of particles which have larger active surface area for the chemical reactions(Saxena et al. 2017)

Many researchers have studied the impact of nano particles with diesel - biodiesel blends on the fuel properties, combustion, Performance and emission characteristics in diesel engine.(Kumar et al. 2017; Najafi 2018; Soudagar et al. 2018; Ağbulut et al. 2020). The impact of MgO nano particles on the cold flow properties, performance and emission characteristics with waste cooking oil biodiesel (Ranjan et al. 
2018) was experimentally studied in a constant speed, single cylinder, water cooled, vertical compression ignition engine and found that, the addition of $\mathrm{MgO}$ in the concentration of $30 \mathrm{ppm}$ gave better fuel properties such as cloud point, cold filter plugging point and pour point. The Specific fuel consumption was higher than petroleum based diesel (PBD) while emissions records lesser than B100 and PBD. The combustion characteristics are comparable with PBD.

Some of the researchers used Aluminium oxide nano particles as a fuel additive with diesel and biodiesel fuels. The performance, combustion and emission characteristics of diesel engine fueled with Aluminium oxide nano particles added jojoba methyl ester (El-Seesy et al. 2018) was investigated and concluded that addition of $\mathrm{Al}_{2} \mathrm{O}_{3}$ enhance the performance, combustion and emission characteristics. However, the preferable emission nature was obtained at $20 \mathrm{mg} / \mathrm{l}$ dosing of $\mathrm{Al}_{2} \mathrm{O}_{3}$ while performance and combustion was better at $40 \mathrm{mg} / \mathrm{l}$ dosage. The comparison of emission and performance suggested that $30 \mathrm{mg} / \mathrm{l}$ dosing gave better result in all aspect. The addition of $\mathrm{Al}_{2} \mathrm{O}_{3}$ with pungamia biodiesel (Sivakumar et al. 2018) was examined in constant speed, single cylinder, direct injection diesel engine and found, that Brake thermal efficiency has increased slightly and brake specific fuel consumption has reduced. The emissions like $\mathrm{CO}, \mathrm{UHC}$ and smoke emission has decreased while NOx has increased. The influence of Aluminium oxide nano particles with honge oil methyl ester on the performance and emission characteristics of diesel engine (Soudagar et al. 2020) was investigated and concluded that addition of $40 \mathrm{ppm} \mathrm{Al} \mathrm{O}_{3}$ resulted in increasing brake thermal efficiency by $10.57 \%$ and Brake specific fuel consumption, $\mathrm{CO}, \mathrm{HC}$ and Smoke were reduced by $11.65 \%, 48.43 \%, 26.72 \%$ and $22.84 \%$ respectively while NOx has increased about $11.27 \%$.

Graphene oxide was used as a nano additive with Jatropha methyl ester and tested in single cylinder air cooled direct injection diesel engine (EL-Seesy et al. 2018) and found that BTE, peak cylinder pressure, the highest rate of pressure rise, and maximum heat release rate were increased by $17 \%, 8 \%, 6 \%$, and $6 \%$ respectively compared to jatropha methyl ester. $\mathrm{HC}$ and $\mathrm{CO}$ were lower than pure jatropha methyl ester about $60 \%$ and $50 \%$ respectively and at full load condition, NOx was reduced by $15 \%$.

The effect of cerium oxide nano particles with mahua methyl ester (B20) in the concentration of $50 \mathrm{ppm}$, 100 ppm and 150 ppm in diesel engine was examined (Kumar et al. 2019) The brake thermal efficiency and combustion pressure data has increased slightly. At the same time, emissions like $\mathrm{CO}, \mathrm{HC}$ and Smoke were reduced dramatically. The NOx emission also decreased due to the oxidation of unburned $\mathrm{Ce}_{2} \mathrm{O}_{3}$ at the exhaust.

The experimental study was conducted by using $\mathrm{ZnO}$ and $\mathrm{TiO}_{2}$ as a fuel additive with Calophyllum inophyllum methyl ester (CIME) as a emulsified fuel in $\mathrm{Cl}$ engine and found that brake thermal efficiency was increased by $5-17 \%$ compared to pure CIME. CO, HC and smoke were drastically decreased when compared to pure CIME and diesel. On the other hand, NOx was lower than pure CIME and higher than Diesel. (Nanthagopal et al. 2017) The effect of ZnO and ethanox as an fuel additive with Calophyllum inophyllum biodiesel in $\mathrm{Cl}$ engine was examined and shown that addition of $100 \mathrm{ppm}$ of $\mathrm{ZnO}$ enhance 
the efficiency by $4.7 \%$ and reduce the NOx emission by $12.6 \%$ at full load condition, due to the catalytic effect of nano particles and macro explosion of water molecules in the fuel emulsion.(Ashok et al. 2017).

From the above literature it is noted that the addition of metal oxide nanoparticles with diesel / biodiesel fuel, significantly affect the performance, combustion and emission characteristics of diesel engine. In this work, the impact of hydrothermally synthesized $\mathrm{ZnO}$ nano particles with waste cooking oil biodiesel on the performance, combustion and emission in single cylinder, water cooled, DI Diesel engine has investigated.

\section{Experimental Setup}

\subsection{Materials and Methods}

\subsubsection{Preparation of Zinc Oxide nano particles}

Zinc oxide nano particles were synthesized by hydrothermal method as shown in fig.1. (Prabhu et al. 2018) In this method zinc acetate is taken as precursor and triethylamine is used as a surfactant. All the reagents were purchased from sigma Aldrich in the analytical grade and used without further pretreatment. In this process required amount of Zinc acetate was dissolved in deionized water with the aid of magnetic stirrer then, $5 \mathrm{ml}$ of triethylamine was added dropwise with continues stirring and finally got a white color precipitate. The obtained precipitate was undergoes hydrothermal treatment at $200^{\circ} \mathrm{C}$ for 12 hours in a Teflon lined autoclave at hot air oven. After hydrothermal treatment the sample was passively cooled to room temperature and collected by centrifugation. Finally the sample was collected after drying in a hot air oven about $80^{\circ} \mathrm{C}$ for 2 hours.

\subsubsection{Preparation of waste cooking oil biodiesel}

Biodiesel from waste cooking oil is an economical way of generating energy and handling waste oil generated in hotels, restaurants, university hostels, etc.(Zareh et al. 2017) Waste cooking oil biodiesel was produced by conventional Trans - esterification process as shown in fig.2. In typical process waste cooking oil and methanol were taken in the molar ratio of 6:1 with Sodium hydroxide as a base catalyst and stirred for 2 hours under $65^{\circ} \mathrm{C}$ with the help of magnetic stirrer, then it is allowed for gravitational separation for 12 hours. Layer of waste cooking oil methyl ester and glycerol were formed as upper and lower layers respectively during gravitational separation process. The waste cooking oil methyl ester was collected and cleaned with deionized water for further purification.(Abed et al. 2018; Ganapathi and Muralidharan 2020)

\subsubsection{Test fuel preparation}

The test fuels were prepared by adding the $\mathrm{ZnO}$ nanoparticles with $\mathrm{B} 20$ by means of agitation. In order to avoid the agglomeration of nano particles in the test fuel, ultra-sonication was adopted.(Gad and Jayaraj 2020; Manigandan et al. 2020) ZnO nano particles were taken in three proportions of $10 \mathrm{ppm}, 20 \mathrm{ppm}$ 
and $30 \mathrm{ppm}$. Initially diesel and biodiesel were taken in the beaker in the ratio of 4:1 and mixed together with the aid of magnetic stirrer to get B20.The measured $\mathrm{ZnO}$ was poured into the B20 and stirred for 30 min, followed by ultra-sonication for $10 \mathrm{~min}$ as shown in fig.3 (Janakiraman et al. 2020) to produce three different fuels such as B20 + 10 ppm ZnO, B20 + 20 ppm ZnO and B20 + 30 ppm ZnO.

\subsubsection{Test Engine Setup}

The engine performance, combustion and emission of prepared test fuels were tested in a single cylinder, four strokes, water-cooled, and vertical diesel engine with a constant speed of $1500 \mathrm{rpm}$ at $0 \%$, $25 \%, 50 \%, 75 \%$ and $100 \%$ loading conditions as specified in table 1 . The test was carried out at fuel injection timing of $23^{\circ} \mathrm{CA}$ before TDC with an injection pressure of 200 bar and $27^{\circ} \mathrm{C}$ of ambient temperature. The arrangement of the crank angle encoder, dynamometer, Computer, data acquisition system, five gas analyser and a smoke meter in the test engine RIG is as shown in fig.4.

Table 1

Engine Specifications

\begin{tabular}{|ll|}
\hline Parameters & Specifications \\
\hline Manufacturer \& Model & Kirloskar \& TV1 \\
\hline No of cylinders & 1 \\
\hline Cylinder arrangement & Vertical \\
\hline No of Strokes & 4 \\
\hline Power & $5.2 \mathrm{~kW}$ at $1500 \mathrm{rpm}$ \\
\hline Cooling type & water cooled \\
\hline Stroke length & $110 \mathrm{~mm}$ \\
\hline Bore diameter & $87.5 \mathrm{~mm}$ \\
\hline Compression ratio & $17.5: 1$ \\
\hline Loading type & Eddy current dynamometer with water cooling \\
\hline
\end{tabular}

\section{Result And Discussion}

\subsection{Nano particles and fuel characterization}

The prepared ZnO nano particles were characterized by XRD, FTIR, SEM, TEM and EDX to identify the crystal structure, surface composition, surface morphology, internal structure and elemental composition. The XRD studies confirmed the prepared material was hexagonal wurtzite crystal of ZnO 
(JCPDS Card no. 16-1451). The diffraction peaks were present at the $2 \theta$ values of $31.770,34.422,36.253$, $47.539,56.603,62.864,66.380,67.963$ and 69.100 were indexed as the (100), (002), (101), (102), (110), (103), (200), (112) and (201) planes as shown in fig.5.(Cao et al. 2017; Prabhu et al. 2018; Hui et al. 2019) the surface composition was studied by FTIR. The spectra was recorded in the range of $400-$ $4000 \mathrm{~cm}^{-1}$ as shown in fig.6. The strong and wide band present around $3400 \mathrm{~cm}^{-1}$ indicates the stretching vibration of $\mathrm{O}-\mathrm{H}$ group due to the presence of water molecules. The intense transmission band located between $480 \mathrm{~cm}^{-1}$ to $580 \mathrm{~cm}^{-1}$ belongs to the stretching vibration of zinc and oxygen molecules.(Pudukudy and Yaakob 2014; Prabhu et al. 2018)

Fig.7. shows the SEM and TEM images which are used to determine the surface morphology as well as internal morphology of the prepared sample. The formation of spindle like structure was identified. The same morphology of ZnO material were reported in previous studies, (Zhou et al. 2013; Ameen et al. 2015; Hui et al. 2019) the TEM images confirms the Spindle like shape which is in good contract with SEM results. The elemental composition of prepared sample is shown in fig.8, it is evident that uniform distribution of Zinc and oxygen throughout the sample and the composition of Zinc is $59 \%$ and Oxygen is $41 \%$.

The fuel properties such as Density, Kinematic viscosity, Calorific value, Flash point and Fire point for test fuels (diesel, B20, B20 + ZnO (10 ppm), B20 + ZnO (20 ppm), B20 + ZnO (30 ppm)) were identified as per the ASTM standards as shown in table.2.

Table 2

Test fuel characterization

\begin{tabular}{|c|c|c|c|c|c|}
\hline $\begin{array}{l}\text { Fuel Name / } \\
\text { Properties }\end{array}$ & $\begin{array}{l}\text { Density } \\
\left(\mathrm{Kg} / \mathrm{m}^{3}\right)\end{array}$ & $\begin{array}{l}\text { Kinematic Viscosity at } \\
40^{\circ} \mathrm{C} \text { (cSt) }\end{array}$ & $\begin{array}{l}\text { Calorific Value } \\
(\mathrm{kJ} / \mathrm{kg})\end{array}$ & $\begin{array}{l}\text { Flash } \\
\left.\text { point }{ }^{\circ} \mathrm{C}\right)\end{array}$ & $\begin{array}{l}\text { Fire } \\
\text { Point } \\
\text { ( }{ }^{\circ} \text { ) }\end{array}$ \\
\hline Diesel & 830 & 1.8 & 42500 & 58 & 62 \\
\hline B20 & 865 & 2.7 & 40625 & 56 & 60 \\
\hline $\begin{array}{l}\mathrm{B} 20+\mathrm{ZnO}(10 \\
\mathrm{ppm})\end{array}$ & 860 & 2.5 & 40723 & 45 & 50 \\
\hline $\begin{array}{l}\mathrm{B} 20+\mathrm{ZnO}(20 \\
\mathrm{ppm})\end{array}$ & 862 & 2.6 & 41014 & 46 & 52 \\
\hline $\begin{array}{l}\mathrm{B} 20+\mathrm{ZnO}(30 \\
\mathrm{ppm})\end{array}$ & 864 & 2.8 & 41306 & 48 & 54 \\
\hline
\end{tabular}




\subsection{Brake Thermal Efficiency}

Brake thermal efficiency is used to find, how effectively an engine has convert chemical energy available in the fuel(Shrivastava et al. 2019). Fig.9. shows the variation of Brake Thermal Efficiency of test fuels with respect to the load. It is clear that the brake thermal efficiency has dramatically increases when increasing the load due to more combustion and reduction of BSFC at higher loading condition. Typically Lower BTE was recorded due to lacking in combustion of air / fuel mixture in the engine cylinder and the lower calorific value of the fuel. B20 accounts lower BTE than diesel fuel owing to irregular air fuel mixing due to their higher viscosity and density that leads to formation of large droplets during atomization of fuel.(Elkelawy et al. 2019) The addition of ZnO nano particles has led to a greater improvement on BTE due to better atomization of fuels, higher calorific value and shorter ignition delay compared to B20 at all load conditions, which is in good agreement with earlier studies(Sajin et al. 2019; Deepak Kumar et al. 2020; Hussain et al. 2020). At the same time an addition of ZnO nano particles with B20 records lower BTE than diesel. Adding 10 ppm, 20 ppm and 30 ppm of ZnO nano particles with B20 at full load condition, produces a greater BTE than B20 about $0.9 \%, 1.4 \%$ and $1.87 \%$ respectively.

\subsection{Brake Specific Fuel Consumption}

Fig.10. shows the variation of BSFC with respect to the load. The variation of BSFC depends on the density, calorific value and viscosity of fuel. BSFC of B20 is always higher than diesel at all loading condition. It may be due to higher viscosity and density of biodiesel that leads to longer ignition delay, compared to diesel(Rajak et al. 2019). The addition of $\mathrm{ZnO}$ nano additives in the concentration of $10 \mathrm{ppm}$ tends to reduce the brake specific fuel consumption than B20 owing to higher calorific value and the better atomization of fuel. Further increasing the concentration of nano additives as $20 \mathrm{ppm}$ and $30 \mathrm{ppm}$ resulted in lower BSFC due to enhanced heat transfer and increasing the contact between fuel and oxidizer as higher surface to volume ratio of nano particles(Devarajan et al. 2019). The BSFC of B20 + $\mathrm{ZnO}(10 \mathrm{ppm}), \mathrm{B} 20+\mathrm{ZnO}(20 \mathrm{ppm})$ and B20 + ZnO (30 ppm) were $0.28 \mathrm{~kg} / \mathrm{kW}-\mathrm{hr}, 0.27 \mathrm{~kg} / \mathrm{kW}-\mathrm{hr}$ and 0.26 $\mathrm{kg} / \mathrm{kW}$-hr respectively, which are $3.44 \%, 6.89 \%$ and $10.34 \%$ lower than B20 at full load condition.

\subsection{Cylinder Pressure}

Fig.11. describes the variation of cylinder pressure based on the crank angle at full load condition. The peak cylinder pressure is recorded as 74.69 bar by diesel fuel due to the lower viscosity, higher calorific value whereas B20 accounts 74.39 bar which is lower than diesel owing to higher viscosity and lower calorific value.(Devarajan et al. 2018) The addition of nano particles with B20 helps to increase the cylinder pressure. It may be due to shorter ignition delay, higher calorific vale and higher heat transfer rate of nano particles. The addition of $\mathrm{ZnO}$ with $\mathrm{B} 20$ in the ratio of $10 \mathrm{ppm}, 20 \mathrm{ppm}$ and 30 
ppm produce peak pressure about 74.56 bar, 74.27 bar and 74.42 bar at full load condition respectively. This trend of increasing cylinder pressure with addition of nano particles were matched with previous studies.(Ashok et al. 2017; Najafi 2018)

\subsection{Ignition Delay}

The time period between start of fuel injection and start of combustion is known as ignition delay(Prabhahar et al. 2019) MFB is used to evaluate the ignition delay. The crank angle at which $10 \%$ of MFB is denoted as CA10 and the crank angle at which the $90 \%$ of MFB is denoted as CA90. The difference between CA10 and CA90 is called as combustion duration at the same time the difference between start of fuel injection and CA10 is known as ignition delay(Cooney et al. 2009; Kim et al. 2019). Since the ignition delay is inversely proportional to the cetane number, biodiesel and its blends often account for shorter ignition delays because it has higher cetane index(Aldhaidhawi et al. 2017; Shrivastava et al. 2019). The ignition delay has decreases when increasing the engine load, and the addition of nano additives tends to lower ignition delay as shown in fig.12. It may due to better catalytic activity of nano particles, as it has large surface area to volume ratio, thus enhance the mixing of fuel with oxidizer.(Aldhaidhawi et al. 2017; Nanthagopal et al. 2017)

\subsection{Net Heat Release Rate}

The heat release rate of the test fuels with respect to the crank angles at full load condition is as shown in fig.13. It shows that the heat release rate has increased when increasing the load due to the fact that engine drawn more fuel to generate more torque which leads to more heat generation(Reang et al. 2020). Heat release rate becomes positive when the combustion is initiated and increases gradually during the primary combustion of fuel. The heat release rate of B20 is lower than diesel at full load condition due to the higher viscosity and poor atomization of biodiesel. The addition of $\mathrm{ZnO}$ nano particles supports to higher cylinder pressure due to the higher surface to volume ratio of nano particles helps to complete combustion resulting in higher heat release rate.(Ranjan et al. 2018; Murugesan et al. 2020) The peak heat release rate for diesel, $\mathrm{B} 20, \mathrm{~B} 20+\mathrm{ZnO}(10 \mathrm{ppm}), \mathrm{B} 20+\mathrm{ZnO}(20 \mathrm{ppm})$ and $\mathrm{B} 20+$ $\mathrm{ZnO}(30 \mathrm{ppm})$ were $40.56 \mathrm{~J}, 39.09 \mathrm{~J}, 42.03 \mathrm{~J}, 40.83 \mathrm{~J}$ and $40.91 \mathrm{~J}$ respectively at $7^{0} \mathrm{CA}$ before TDC at full load condition.

\section{7. $\mathrm{CO}$ emission}

More carbon monoxide emissions have resulted from incomplete combustion caused by improper mixing of fuel and oxidant, lack of oxygen, and lower cylinder temperatures(Mehregan and Moghiman 2018). The variation of $\mathrm{CO}$ emission with respect to the load is as shown in fig.14. It shows that the $\mathrm{CO}$ emission 
was decreases with increasing load, except full load condition for all fuel blends. It is due to lower air / fuel ratio and lower in-cylinder temperature at zero load condition has led to partial combustion, when increasing the load the surplus amount of oxygen and higher in cylinder temperature affirms complete combustion and resulted in lower emission of CO(Chandrasekaran et al. 2016; Fayad and Dhahad 2021). at the same time, engine drawn more fuel to generate extreme torque at full load condition that results in more emission of $\mathrm{CO}$ (Tan et al. 2012; Anchupogu et al. 2018). The CO emission of B20 records lower than diesel for all loading conditions due to more availability of oxygen in the biodiesel helps to enhance the combustion(Jiaqiang et al. 2018). Addition of $\mathrm{ZnO}$ nano particles helps to further reduction in $\mathrm{CO}$ which may due to the catalytic action of nano particles that helps to enhance the combustion process. The same way of reduction in $\mathrm{CO}$ when adding nano particles reported in earlier studies.(Murugesan et al. 2020; Ağbulut et al. 2021; PALANI et al. 2021). The CO emission of B20, B20 + ZnO (10 ppm), B20 + ZnO (20 ppm), and B20 $+\mathrm{ZnO}(30 \mathrm{ppm}$ ) records $10.6 \%, 13.63 \%, 17.4 \%$ and $20 \%$ lower than diesel fuel at full load condition.

\section{8. $\mathrm{CO}_{2}$ Emission}

Higher oxygen content in the fuel and complete combustion results in greater emission of $\mathrm{CO}_{2}$ which is inversely proportional to the emission of CO(Ashok et al. 2020; Soudagar et al. 2021). the variation of $\mathrm{CO}_{2}$ with respect to the load for different test fuels are as shown in fig.15. It shows that $\mathrm{CO}_{2}$ emission has slightly increases when increasing the load and B20 accounts maximum when compared to diesel at all loading condition owing to higher oxygen content in the biodiesel that tends to complete combustion(Ranjan et al. 2018). Further addition of $\mathrm{ZnO}$ nano particles with $\mathrm{B} 20$ helps to enhance the combustion that leads to more emission of $\mathrm{CO}_{2}$ due to the higher surface to volume ratio of nano particles involved as a combustion catalyst. The results revealed that addition of $\mathrm{ZnO}$ nano particles with $\mathrm{B} 20$ generate more $\mathrm{CO}_{2}$ for all loading conditions, which is evident that higher concentration of $\mathrm{ZnO}$ nano particles resulting in better combustion. The $\mathrm{CO}_{2}$ emissions of $\mathrm{B} 20, \mathrm{~B} 20+\mathrm{ZnO}(10 \mathrm{ppm}), \mathrm{B} 20+\mathrm{ZnO}(20$ $\mathrm{ppm}$ ), and B20 + ZnO (30 ppm) were 3.12\%, 3.46\%, 4.13\% and 4.35\% higher than diesel at full load condition. This results are in decent agreement with previous investigations.(Chandrasekaran et al. 2016; Fayad and Dhahad 2021)

\subsection{Smoke Opacity}

Fig.16.illustrated discrepancy of smoke opacity of diesel, B20 and various concentration of ZnO with B20. Smoke emission has been increasing due to partial combustion at higher loads as more fuel entering the cylinders to maintain constant speed.(Ranjan et al. 2018) Smoke opacity of B20 was lower at all loading conditions, because of higher oxygen levels which facilitates the better combustion and further addition of $\mathrm{ZnO}$ nano particles with $\mathrm{B} 20$ resulting in reduction of smoke emission than B20 owing 
to shorter ignition delay and improved combustion due to larger surface to volume ratio of $\mathrm{ZnO}$ nano particles that act as combustion catalyst (Kumar et al. 2020; Venu and Appavu 2020a). The average reduction of Smoke emissions for B20, B20 + ZnO (10 ppm), B20 + ZnO (20ppm) and B20 + ZnO (30 ppm) were noted that, $2.92 \%, 3.79 \%, 9 \%$ and $15.4 \%$ when compared to diesel. This similar results were noted in previous investigations.(Prabu and Anand 2016; El-Seesy et al. 2018; Sadhik Basha 2018; Gad et al. 2021)

\subsection{HC Emission}

Lower cylinder temperature, deposits on the combustion chamber walls, non-stoichiometric Air / fuel ratio and incomplete combustion are the factors that greatly contributes to the more release of UHC (Prabu and Anand 2016; Hosseini et al. 2017). In all cases, the emission of UHC were noted in the descending order of Diesel, B20, B20 + ZnO (10 ppm), B20 + ZnO (20ppm) and B20 + ZnO (30 ppm) as shown in fig.17. owing to higher oxygen content in the biodiesel helps to complete combustion. However, $\mathrm{ZnO}$ nano particles with the concentration of 30 ppm added with B20 generates lower UHC than all other fuels. it is due to that large surface to volume ratio, higher heat transfer rate, oxygen availability and catalytic action of nanoparticles tends to complete combustion(Venu and Appavu 2020a, b).

\subsection{NOx emission}

Fig.18. depicts the NOx emission pattern of tested fuels. NOx is produced owing to higher combustion temperatures, availability of oxygen and lower ignition delay (Gad and Jayaraj 2020) the NOx emission of B20 was higher than all other fuels regardless of loading condition. It is due to the more oxygen content in the biodiesel that increases the local combustion temperature.(Hoseini et al. 2020) The addition of $\mathrm{ZnO}$ nano particles with $\mathrm{B} 20$ reduces the NOx emission due to the shorter ignition delay(Rangabashiam et al. 2020). At the same time, increasing the concentration of $\mathrm{ZnO}$ nano particles leads to increase in NOx emission due to the availability of more oxygen in $\mathrm{ZnO}$. The NOx emissions of $\mathrm{B} 20, \mathrm{~B} 20+\mathrm{ZnO}(10 \mathrm{ppm}), \mathrm{B} 20+\mathrm{ZnO}(20 \mathrm{ppm})$ and B20 + ZnO (30 ppm )were 12.66\%, 4.01\%, 7.41\% and $7.47 \%$ higher than diesel at full load condition.

\section{Conclusion}

$\mathrm{ZnO}$ nanoparticles were prepared by hydrothermal method and waste cooking oil biodiesel was prepared via Trans-esterification process. ZnO nano particles were mixed with B20 in the concentration of 10 ppm, 20 ppm and 30 ppm with the aid of magnetic stirrer and ultrasonicator. The prepared fuels were tested in single cylinder, four stroke, water cooled and vertical diesel engine at diffrerent loading conditions. The following conclusion were made. 
1. The addition of Zinc Oxide nano particles helps to increase the calorific value and reduce the viscosity compared to B20. The shorter ignition delay was noted when the concentration of nano particles increases.

2. The addition of nano particles helps to improve the BTE and reduce the fuel consumption compared to B20.

3. The addition of nano particles reduces the emissions like $\mathrm{CO}, \mathrm{HC}$ and smoke opacity when compared to diesel and B20.

4. The emission of NOx has increased when increasing the concentration of nano particles at the same time NOx was lower than B20.

\section{Nomenclature}

B20-20\% biodiesel + 80\% Diesel

ZnO-Zinc Oxide

ppm-parts per million

$\mathrm{B} 20+\mathrm{ZnO}(10 \mathrm{ppm})-20 \%$ biodiesel $+80 \%$ Diesel $+10 \mathrm{ppm}$ of $\mathrm{ZnO}$

B20 + ZnO (20ppm)-20\% biodiesel $+80 \%$ Diesel +20 ppm of ZnO

B20 + ZnO (30 ppm)-20\% biodiesel $+80 \%$ Diesel $+30 p p m$ of ZnO

BTE-Brake Thermal Efficiency

BSFC-Brake specific Fuel Consumption

co-Carbon Monoxide

$\mathrm{CO}_{2}$-Carbon Dioxide

UHC -Unburned Hydrocarbon

NOx -Oxides of Nitrogen

CA -Crank Angle

MFB -Mass Fraction Burned

TDC- Top Dead Centre

XRD - X-Ray Diffraction

FTIR-Spectroscopy-Fourier Transform Infrared Spectroscopy 
SEM- Scanning Electron Microscope

TEM -Tandem Electron Microscope

EDX-Spectroscopy-Energy Dispersive X - ray Spectroscopy

\section{Declarations}

\section{Conflict of Interest}

The authors declare no conflict of interest.

\section{Availability of data and material}

No data associated with this article.

\section{Code availability}

Not applicable.

\section{Acknowledgement}

One of the authors M.Dhanarasu acknowledges Periyar University for providing financial support in the scheme of University Research Fellowship (URF).

\section{References}

Abed KA, El Morsi AK, Sayed MM, et al (2018) Effect of waste cooking-oil biodiesel on performance and exhaust emissions of a diesel engine. Egypt J Pet 27:985-989.

https://doi.org/10.1016/j.ejpe.2018.02.008

Ağbulut Ü, Gürel AE, Sarıdemir S (2021) Experimental investigation and prediction of performance and emission responses of a $\mathrm{Cl}$ engine fuelled with different metal-oxide based nanoparticles-diesel blends using different machine learning algorithms. Energy 215:. https://doi.org/10.1016/j.energy.2020.119076

Ağbulut Ü, Karagöz M, Sarıdemir S, Öztürk A (2020) Impact of various metal-oxide based nanoparticles and biodiesel blends on the combustion, performance, emission, vibration and noise characteristics of a Cl engine. Fuel 270:. https://doi.org/10.1016/j.fuel.2020.117521

Ahmed A, Shah AN, Azam A, et al (2020) Environment-friendly novel fuel additives: Investigation of the effects of graphite nanoparticles on performance and regulated gaseous emissions of $\mathrm{Cl}$ engine. Energy Convers Manag 211:. https://doi.org/10.1016/j.enconman.2020.112748

Aldhaidhawi M, Chiriac R, Badescu V (2017) Ignition delay, combustion and emission characteristics of Diesel engine fueled with rapeseed biodiesel - A literature review. Renew Sustain Energy Rev 73:178- 
Ameen S, Akhtar MS, Shin HS (2015) Spindles shaped ZnO modified glassy carbon electrode for the selective monitoring of piperidine. Mater Lett 148:188-191. https://doi.org/10.1016/j.matlet.2015.02.049

Anchupogu P, Rao LN, Banavathu B (2018) Effect of alumina nano additives into biodiesel-diesel blends on the combustion performance and emission characteristics of a diesel engine with exhaust gas recirculation. Environ Sci Pollut Res 25:23294-23306. https://doi.org/10.1007/s11356-018-2366-7

Ashok B, Nanthagopal K, Chyuan OH, et al (2020) Multi-functional fuel additive as a combustion catalyst for diesel and biodiesel in $\mathrm{Cl}$ engine characteristics. Fuel 278:.

https://doi.org/10.1016/j.fuel.2020.118250

Ashok B, Nanthagopal K, Mohan A, et al (2017) Comparative analysis on the effect of zinc oxide and ethanox as additives with biodiesel in Cl engine. Energy 140:352-364.

https://doi.org/10.1016/j.energy.2017.09.021

Cao Y, Chen TT, Wang W, et al (2017) Construction and functional assessment of zein thin film incorporating spindle-like ZnO crystals. RSC Adv 7:2180-2185. https://doi.org/10.1039/c6ra25290g

Chacko N, Jeyaseelan T (2020) Comparative evaluation of graphene oxide and graphene nanoplatelets as fuel additives on the combustion and emission characteristics of a diesel engine fuelled with diesel and biodiesel blend. Fuel Process Technol 204:. https://doi.org/10.1016/j.fuproc.2020.106406

Chandrasekaran V, Arthanarisamy M, Nachiappan P, et al (2016) The role of nano additives for biodiesel and diesel blended transportation fuels. Transp Res Part D Transp Environ 46:145-156.

https://doi.org/10.1016/j.trd.2016.03.015

Cooney CP, Yeliana, Worm JJ, Naber JD (2009) Combustion characterization in an internal combustion engine with ethanol - Gasoline blended fuels varying compression ratios and ignition timing. Energy and Fuels 23:2319-2324. https://doi.org/10.1021/ef800899r

Deepak Kumar T, Sameer Hussain S, Ramesha DK (2020) Effect of a zinc oxide nanoparticle fuel additive on the performance and emission characteristics of a $\mathrm{Cl}$ engine fuelled with cotton seed biodiesel blends. Mater Today Proc 26:2374-2378. https://doi.org/10.1016/j.matpr.2020.02.509

Devarajan Y, Mahalingam A, Munuswamy DB, Arunkumar T (2018) Combustion, Performance, and Emission Study of a Research Diesel Engine Fueled with Palm Oil Biodiesel and Its Additive. Energy and Fuels 32:8447-8452. https://doi.org/10.1021/acs.energyfuels.8b01125

Devarajan Y, Munuswamy DB, Mahalingam A (2019) Investigation on behavior of diesel engine performance, emission, and combustion characteristics using nano-additive in neat biodiesel. Heat Mass Transf und Stoffuebertragung 55:1641-1650. https://doi.org/10.1007/s00231-018-02537-2 
El-Seesy Al, Attia AMA, El-Batsh HM (2018) The effect of Aluminum oxide nanoparticles addition with Jojoba methyl ester-diesel fuel blend on a diesel engine performance, combustion and emission characteristics. Fuel 224:147-166. https://doi.org/10.1016/j.fuel.2018.03.076

EL-Seesy Al, Hassan H, Ookawara S (2018) Performance, combustion, and emission characteristics of a diesel engine fueled with Jatropha methyl ester and graphene oxide additives. Energy Convers Manag 166:674-686. https://doi.org/10.1016/j.enconman.2018.04.049

Elkelawy M, Alm-Eldin Bastawissi H, Esmaeil KK, et al (2019) Experimental studies on the biodiesel production parameters optimization of sunflower and soybean oil mixture and DI engine combustion, performance, and emission analysis fueled with diesel/biodiesel blends. Fuel 255:. https://doi.org/10.1016/j.fuel.2019.115791

Fayad MA, Dhahad HA (2021) Effects of adding aluminum oxide nanoparticles to butanol-diesel blends on performance, particulate matter, and emission characteristics of diesel engine. Fuel 286:. https://doi.org/10.1016/j.fuel.2020.119363

Gad MS, Jayaraj S (2020) A comparative study on the effect of nano-additives on the performance and emissions of a diesel engine run on Jatropha biodiesel. Fuel 267:.

https://doi.org/10.1016/j.fuel.2020.117168

Gad MS, Kamel BM, Anjum Badruddin I (2021) Improving the diesel engine performance, emissions and combustion characteristics using biodiesel with carbon nanomaterials. Fuel 288:.

https://doi.org/10.1016/j.fuel.2020.119665

Ganapathi A, Muralidharan K (2020) Impact of Indian Geranium Grass Biodiesel Blends on Performance, Combustion and Emission Characteristics. Int J Thermophys 41:. https://doi.org/10.1007/s10765-02002706-8

Hoseini SS, Najafi G, Ghobadian B, et al (2020) Performance and emission characteristics of a Cl engine using graphene oxide (GO) nano-particles additives in biodiesel-diesel blends. Renew Energy 145:458465. https://doi.org/10.1016/j.renene.2019.06.006

Hosseini SE, Wahid MA (2012) Necessity of biodiesel utilization as a source of renewable energy in Malaysia. Renew Sustain Energy Rev 16:5732-5740. https://doi.org/10.1016/j.rser.2012.05.025

Hosseini SH, Taghizadeh-Alisaraei A, Ghobadian B, Abbaszadeh-Mayvan A (2017) Effect of added alumina as nano-catalyst to diesel-biodiesel blends on performance and emission characteristics of $\mathrm{Cl}$ engine. Energy 124:543-552. https://doi.org/10.1016/j.energy.2017.02.109

Hosseinzadeh-Bandbafha $\mathrm{H}$, Tabatabaei M, Aghbashlo M, et al (2018) A comprehensive review on the environmental impacts of diesel/biodiesel additives. Energy Convers Manag 174:579-614. https://doi.org/10.1016/j.enconman.2018.08.050 
Hui A, Dong S, Kang Y, et al (2019) Hydrothermal fabrication of spindle-shaped ZnO/palygorskite nanocomposites using nonionic surfactant for enhancement of antibacterial activity. Nanomaterials 9:. https://doi.org/10.3390/nano9101453

Hussain F, Soudagar MEM, Afzal A, et al (2020) Enhancement in Combustion, Performance, and Emission Characteristics of a Diesel Engine Fueled with Ce-ZnO Nanoparticle Additive Added to Soybean Biodiesel Blends. Energies 13:4578. https://doi.org/10.3390/en13174578

Janakiraman S, Lakshmanan T, Chandran V, Subramani L (2020) Comparative behavior of various nano additives in a DIESEL engine powered by novel Garcinia gummi-gutta biodiesel. J Clean Prod 245:. https://doi.org/10.1016/j.jclepro.2019.118940

Jiaqiang E, Zhang Z, Chen J, et al (2018) Performance and emission evaluation of a marine diesel engine fueled by water biodiesel-diesel emulsion blends with a fuel additive of a cerium oxide nanoparticle. Energy Convers Manag 169:194-205. https://doi.org/10.1016/j.enconman.2018.05.073

Kim HY, Ge JC, Choi NJ (2019) Effects of fuel injection pressure on combustion and emission characteristics under low speed conditions in a diesel engine fueled with palm oil biodiesel. Energies 12 :. https://doi.org/10.3390/en12173264

Kumar AM, Kannan M, Nataraj G (2020) A study on performance, emission and combustion characteristics of diesel engine powered by nano-emulsion of waste orange peel oil biodiesel. Renew Energy 146:1781-1795. https://doi.org/10.1016/j.renene.2019.06.168

Kumar MV, Babu AV, Kumar PR (2019) Influence of metal-based cerium oxide nanoparticle additive on performance, combustion, and emissions with biodiesel in diesel engine. Environ Sci Pollut Res 26:76517664. https://doi.org/10.1007/s11356-018-04075-0

Kumar S, Dinesha P, Bran I (2017) Influence of nanoparticles on the performance and emission characteristics of a biodiesel fuelled engine: An experimental analysis. Energy 140:98-105. https://doi.org/10.1016/j.energy.2017.08.079

Manigandan S, Sarweswaran R, Booma Devi P, et al (2020) Comparative study of nanoadditives TiO2, CNT, Al2O3, $\mathrm{CuO}$ and $\mathrm{CeO} 2$ on reduction of diesel engine emission operating on hydrogen fuel blends. Fuel 262:. https://doi.org/10.1016/j.fuel.2019.116336

Mehregan M, Moghiman M (2018) Effects of nano-additives on pollutants emission and engine performance in a urea-SCR equipped diesel engine fueled with blended-biodiesel. Fuel 222:402-406. https://doi.org/10.1016/j.fuel.2018.02.172

Murugesan A, Avinash A, Gunasekaran EJ, Murugaganesan A (2020) Multivariate analysis of nano additives on biodiesel fuelled engine characteristics. Fuel 275:.

https://doi.org/10.1016/j.fuel.2020.117922

Page 15/34 
Najafi G (2018) Diesel engine combustion characteristics using nano-particles in biodiesel-diesel blends. Fuel 212:668-678. https://doi.org/10.1016/j.fuel.2017.10.001

Nanthagopal K, Ashok B, Tamilarasu A, et al (2017) Influence on the effect of zinc oxide and titanium dioxide nanoparticles as an additive with Calophyllum inophyllum methyl ester in a $\mathrm{Cl}$ engine. Energy Convers Manag 146:8-19. https://doi.org/10.1016/j.enconman.2017.05.021

Palani Y, Devarajan C, Manickam D, Thanikodi S (2021) Performance and emission characteristics of biodiesel-blend in diesel engine: A review. Environ Eng Res. https://doi.org/10.4491/eer.2020.338

Prabhahar M, Deh Kiani MK, Bhaskar K, et al (2019) Studies on pongamia oil methyl ester fueled direct injection diesel engine to increase efficiency and to reduce harmful emissions. Adv Biofuels Appl Technol Environ Sustain 217-245. https://doi.org/10.1016/B978-0-08-102791-2.00009-X

Prabhu S, Pudukudy M, Sohila S, et al (2018) Synthesis, structural and optical properties of ZnO spindle/reduced graphene oxide composites with enhanced photocatalytic activity under visible light irradiation. Opt Mater (Amst) 79:186-195. https://doi.org/10.1016/j.optmat.2018.02.061

Prabu A, Anand RB (2016) Emission control strategy by adding alumina and cerium oxide nano particle in biodiesel. J Energy Inst 89:366-372. https://doi.org/10.1016/j.joei.2015.03.003

Pudukudy M, Yaakob Z (2014) Simple chemical synthesis of novel ZnO nanostructures: Role of counter ions. Solid State Sci 30:78-88. https://doi.org/10.1016/j.solidstatesciences.2014.02.008

Rajak U, Nashine P, Verma TN (2019) Assessment of diesel engine performance using spirulina microalgae biodiesel. Energy 166:1025-1036. https://doi.org/10.1016/j.energy.2018.10.098

Rangabashiam D, Rathinam S, Subbiah G, et al (2020) Emission behaviour studies on the cause of ZnO nanoparticle inclusion in neat biodiesel. Energy Sources, Part A Recover Util Environ Eff 42:1989-1996. https://doi.org/10.1080/15567036.2019.1604909

Ranjan A, Dawn SS, Jayaprabakar J, et al (2018) Experimental investigation on effect of MgO nanoparticles on cold flow properties, performance, emission and combustion characteristics of waste cooking oil biodiesel. Fuel 220:780-791. https://doi.org/10.1016/j.fuel.2018.02.057

Reang NM, Dey S, Debbarma B, et al (2020) Experimental investigation on combustion, performance and emission analysis of 4-stroke single cylinder diesel engine fuelled with neem methyl ester-rice wine alcohol-diesel blend. Fuel 271:117602. https://doi.org/10.1016/j.fuel.2020.117602

Sadhik Basha J (2018) Impact of Carbon Nanotubes and Di-Ethyl Ether as additives with biodiesel emulsion fuels in a diesel engine - An experimental investigation. J Energy Inst 91:289-303. https://doi.org/10.1016/j.joei.2016.11.006 
Sajin JB, Pillai GO, Kesavapillai M, Varghese S (2019) Effect of nanoparticle on emission and performance characteristics of biodiesel. Int J Ambient Energy 1-7.

https://doi.org/10.1080/01430750.2019.1611650

Saxena V, Kumar N, Saxena VK (2017) A comprehensive review on combustion and stability aspects of metal nanoparticles and its additive effect on diesel and biodiesel fuelled C.I. engine. Renew Sustain Energy Rev 70:563-588. https://doi.org/10.1016/j.rser.2016.11.067

Shrivastava P, Verma TN, Pugazhendhi A (2019) An experimental evaluation of engine performance and emisssion characteristics of $\mathrm{Cl}$ engine operated with Roselle and Karanja biodiesel. Fuel 254:. https://doi.org/10.1016/j.fuel.2019.115652

Sivakumar M, Shanmuga Sundaram N, Ramesh kumar R, Syed Thasthagir MH (2018) Effect of aluminium oxide nanoparticles blended pongamia methyl ester on performance, combustion and emission characteristics of diesel engine. Renew Energy 116:518-526.

https://doi.org/10.1016/j.renene.2017.10.002

Soudagar MEM, Mujtaba MA, Safaei MR, et al (2021) Effect of Sr@ZnO nanoparticles and Ricinus communis biodiesel-diesel fuel blends on modified CRDI diesel engine characteristics. Energy 215:. https://doi.org/10.1016/j.energy.2020.119094

Soudagar MEM, Nik-Ghazali NN, Abul Kalam M, et al (2018) The effect of nano-additives in dieselbiodiesel fuel blends: A comprehensive review on stability, engine performance and emission characteristics. Energy Convers Manag 178:146-177. https://doi.org/10.1016/j.enconman.2018.10.019

Soudagar MEM, Nik-Ghazali NN, Kalam MA, et al (2020) An investigation on the influence of aluminium oxide nano-additive and honge oil methyl ester on engine performance, combustion and emission characteristics. Renew Energy 146:2291-2307. https://doi.org/10.1016/j.renene.2019.08.025

Tan P qiang, Hu Z yuan, Lou D ming, Li Z jun (2012) Exhaust emissions from a light-duty diesel engine with Jatropha biodiesel fuel. Energy 39:356-362. https://doi.org/10.1016/j.energy.2012.01.002

Tomar M, Kumar N (2020) Influence of nanoadditives on the performance and emission characteristics of a Cl engine fuelled with diesel, biodiesel, and blends-a review. Energy Sources, Part A Recover Util Environ Eff 42:2944-2961. https://doi.org/10.1080/15567036.2019.1623347

Venu H, Appavu P (2020a) Al203 nano additives blended Polanga biodiesel as a potential alternative fuel for existing unmodified DI diesel engine. Fuel 279:. https://doi.org/10.1016/j.fuel.2020.118518

Venu H, Appavu P (2020b) An experimental assessment on the influence of nanoparticles in calophyllum inophyllum biodiesel operated diesel engine. Energy Sources, Part A Recover Util Environ Eff. https://doi.org/10.1080/15567036.2020.1839599 
Zareh P, Zare AA, Ghobadian B (2017) Comparative assessment of performance and emission characteristics of castor, coconut and waste cooking based biodiesel as fuel in a diesel engine. Energy 139:883-894. https://doi.org/10.1016/j.energy.2017.08.040

Zhou K, Zhang Q, Shi Y, et al (2013) A facile method for preparation ZnO with different morphology and their optical property. J Alloys Compd 577:389-394. https://doi.org/10.1016/j.jallcom.2013.06.013

\section{Figures}
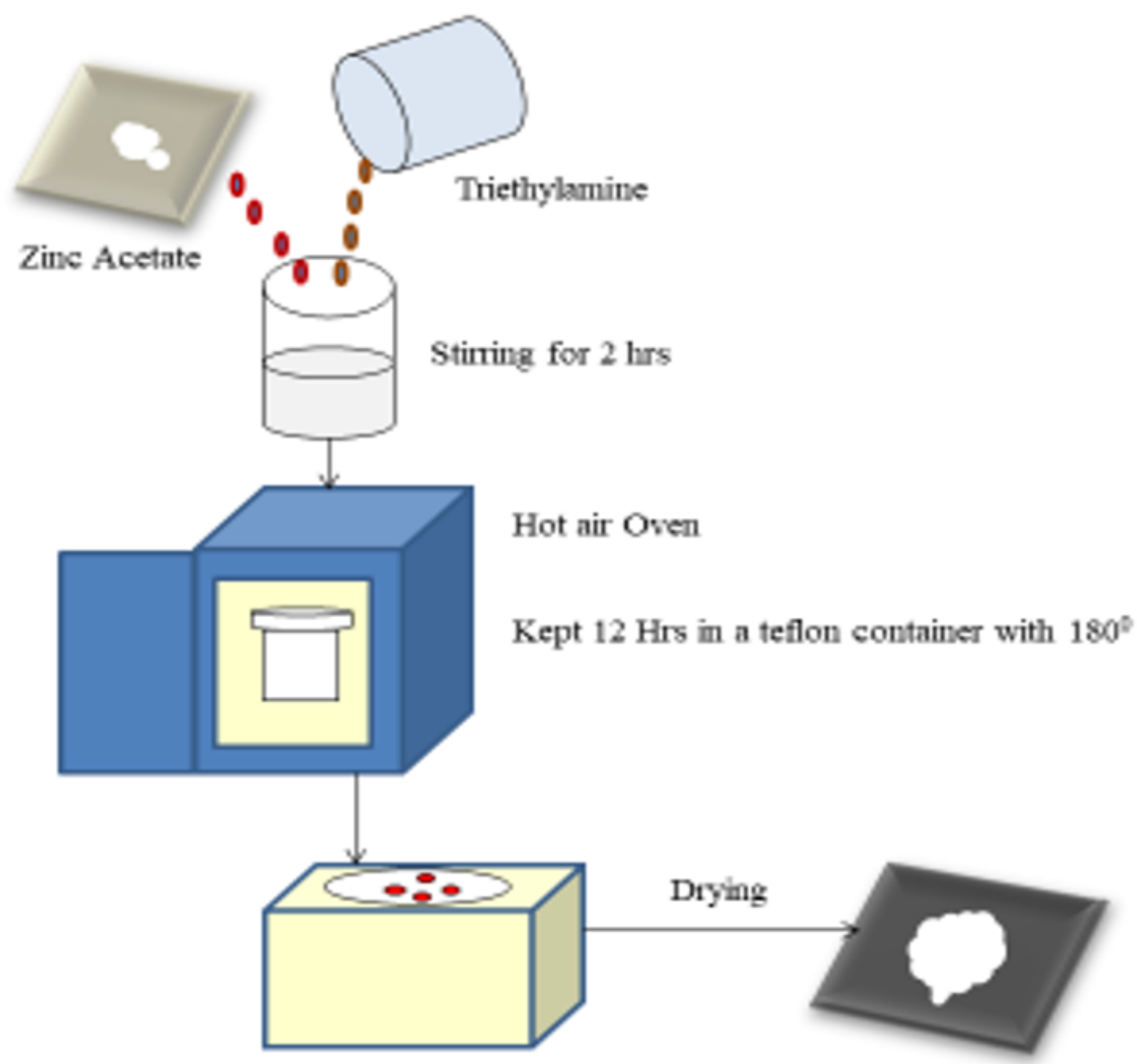

Centrifuge 
Figure 1

Synthesis of Zinc Oxide nano particles

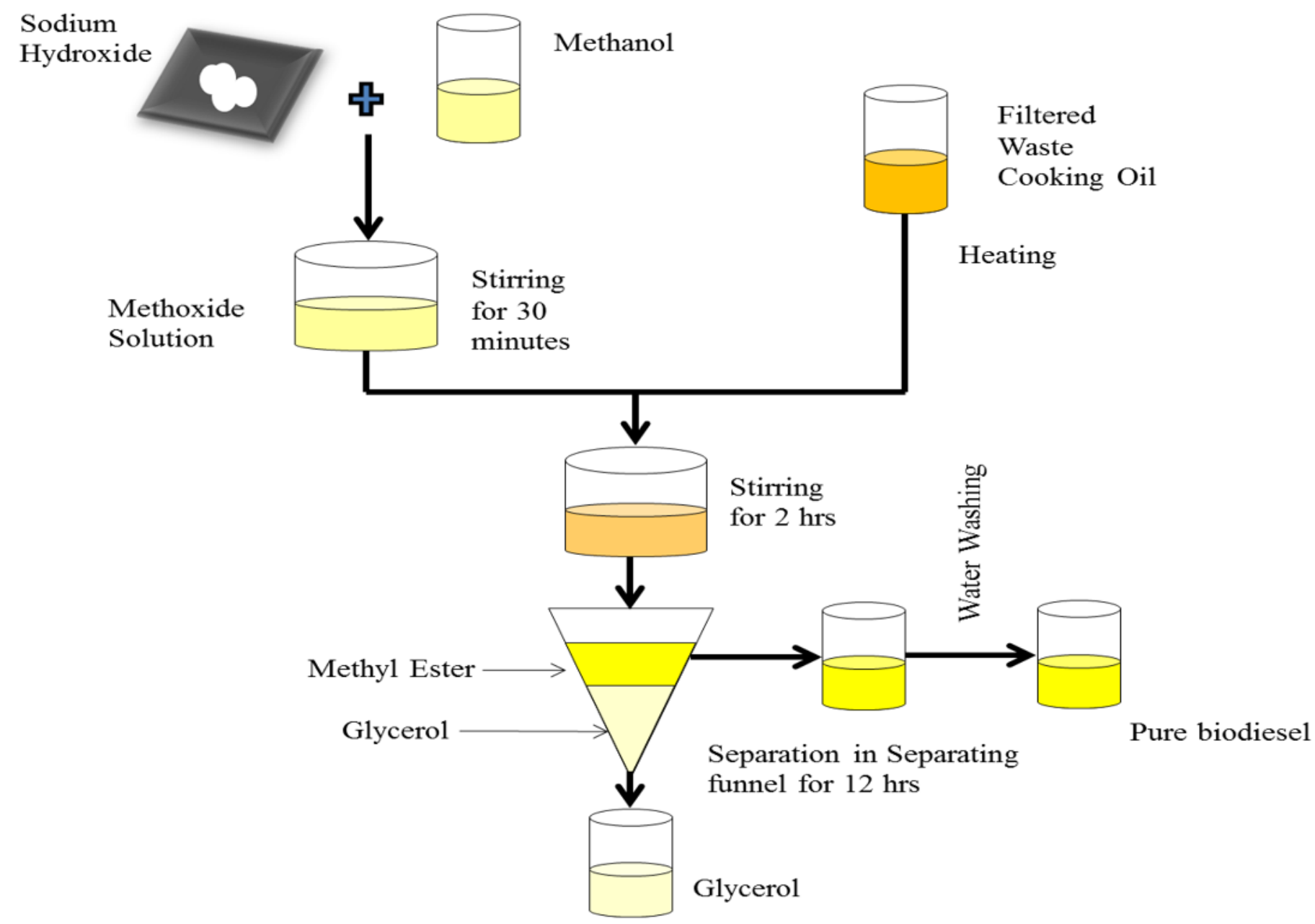

Figure 2

Biodiesel Preparation 


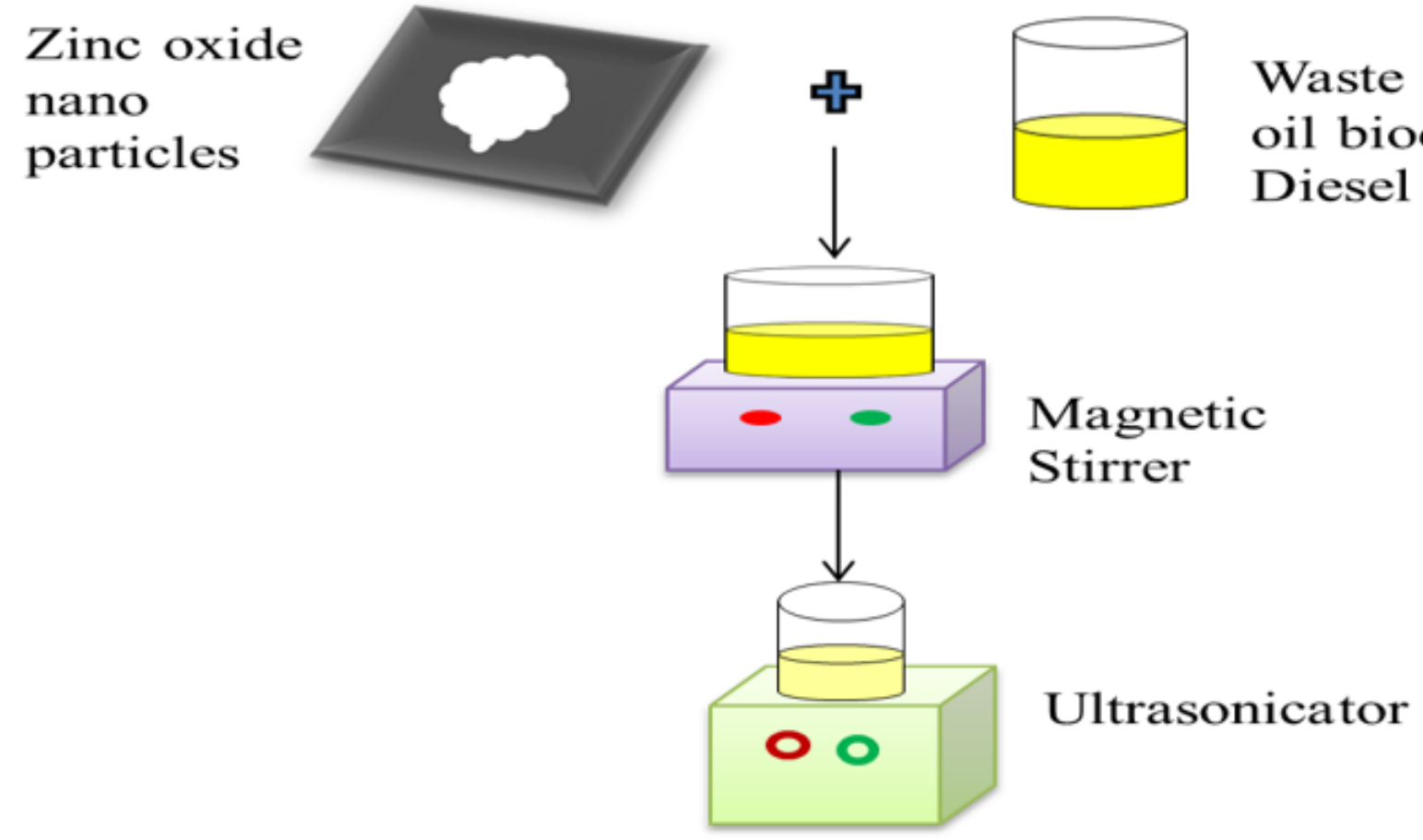

Figure 3

ZnO Addition with Biodiesel

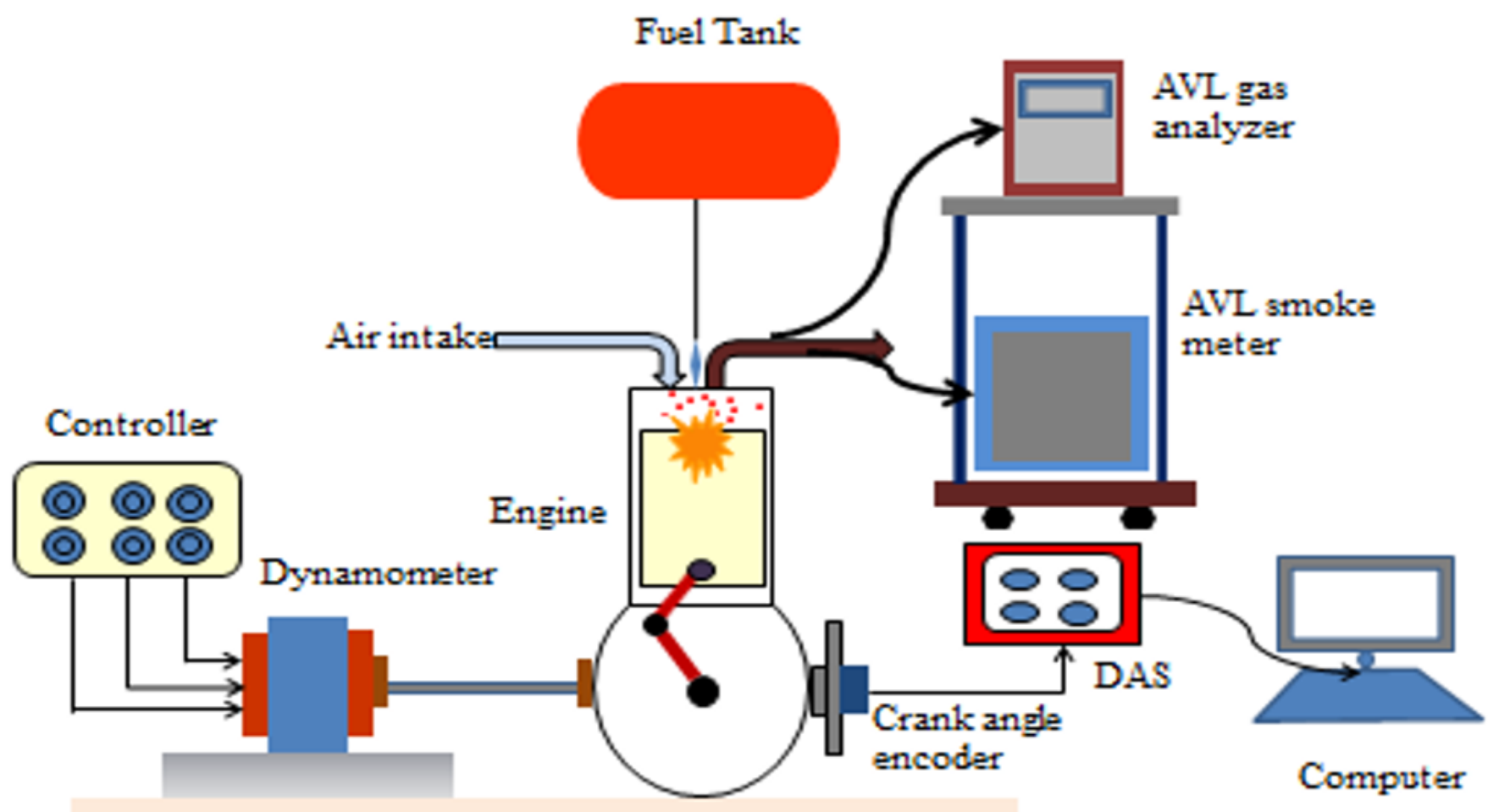

Figure 4 


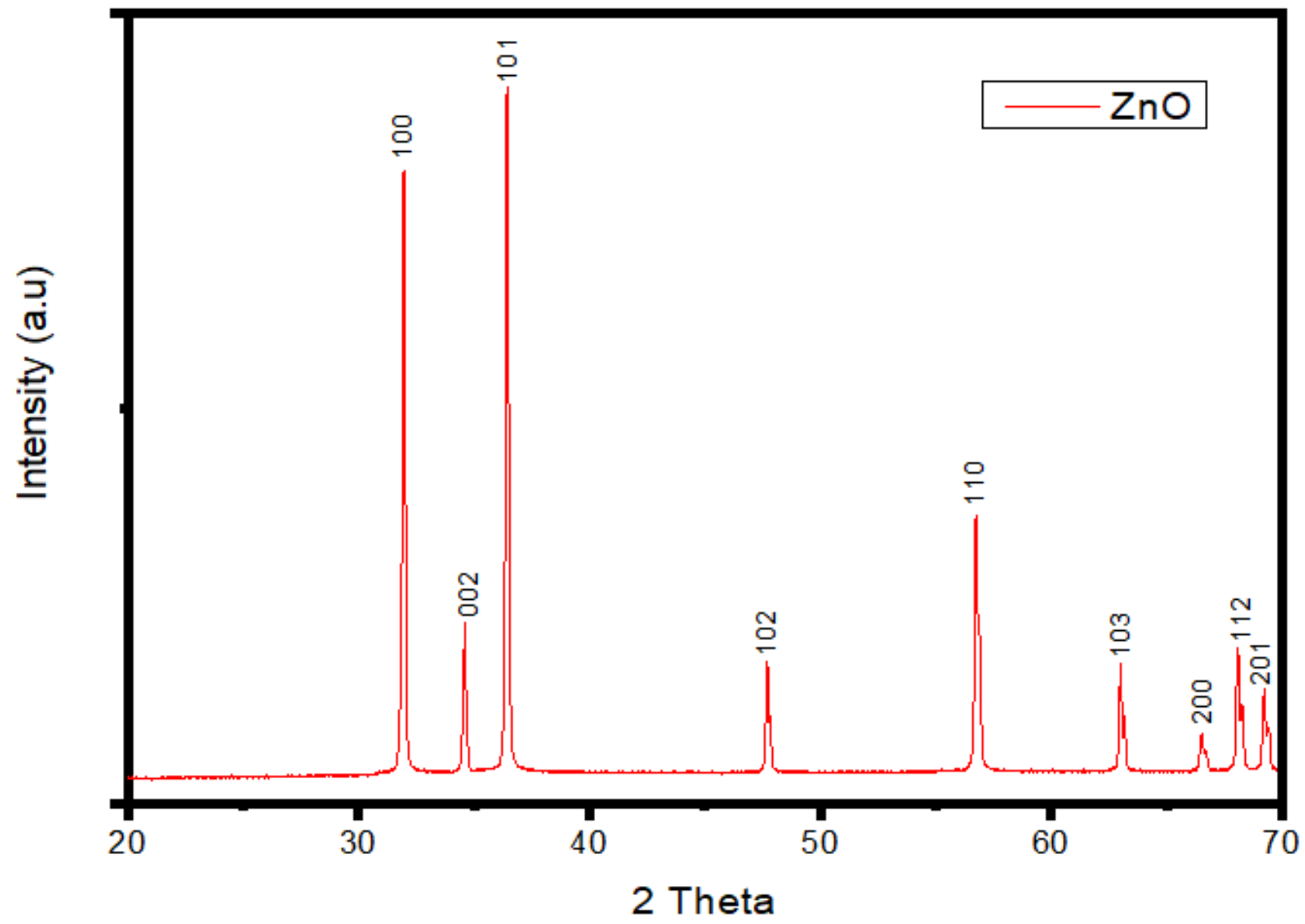

Figure 5

XRD Pattern of ZnO 


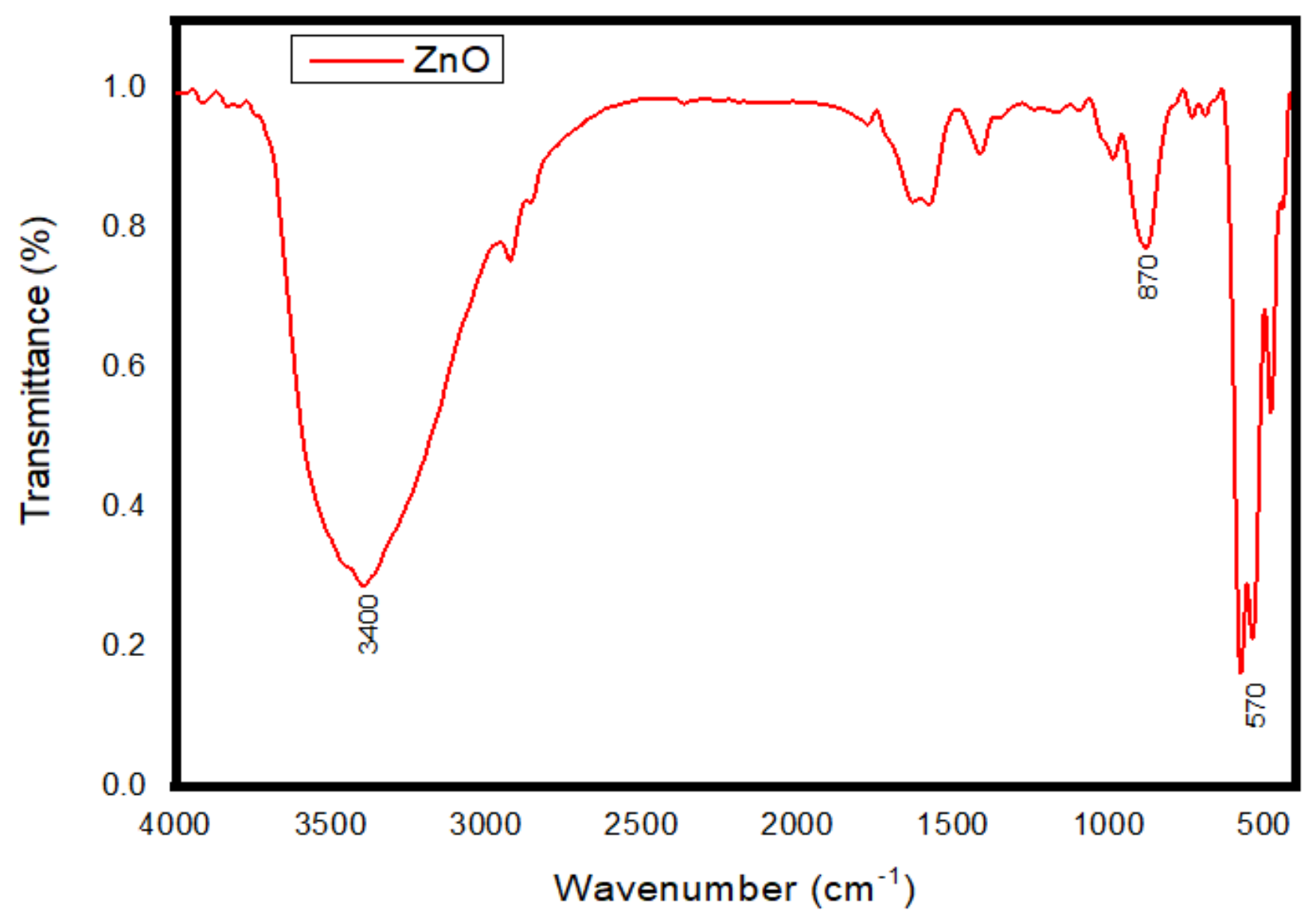

Figure 6

FTIR Spectrum of ZnO 


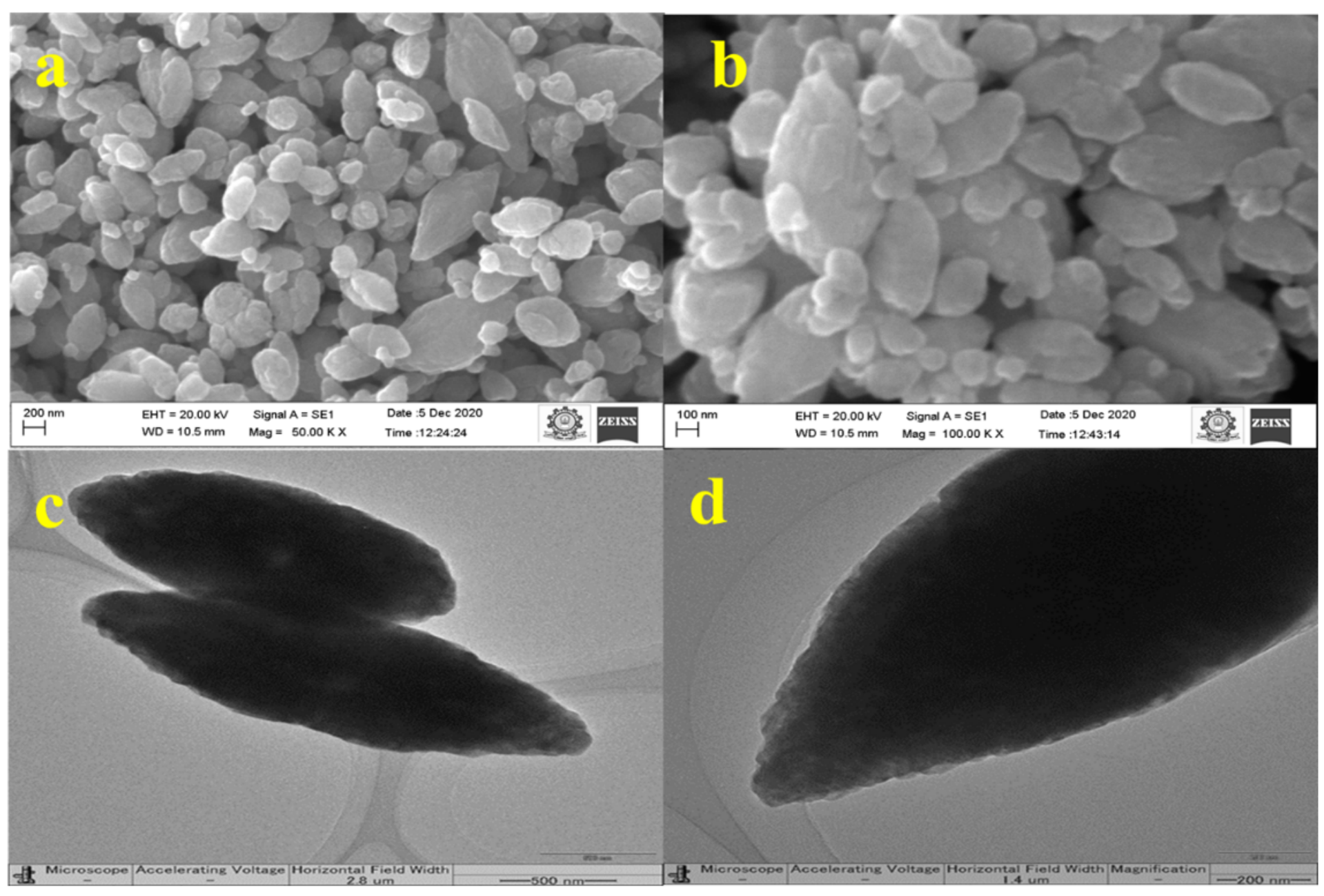

Figure 7

a, b SEM images and c, d TEM images of ZnO 


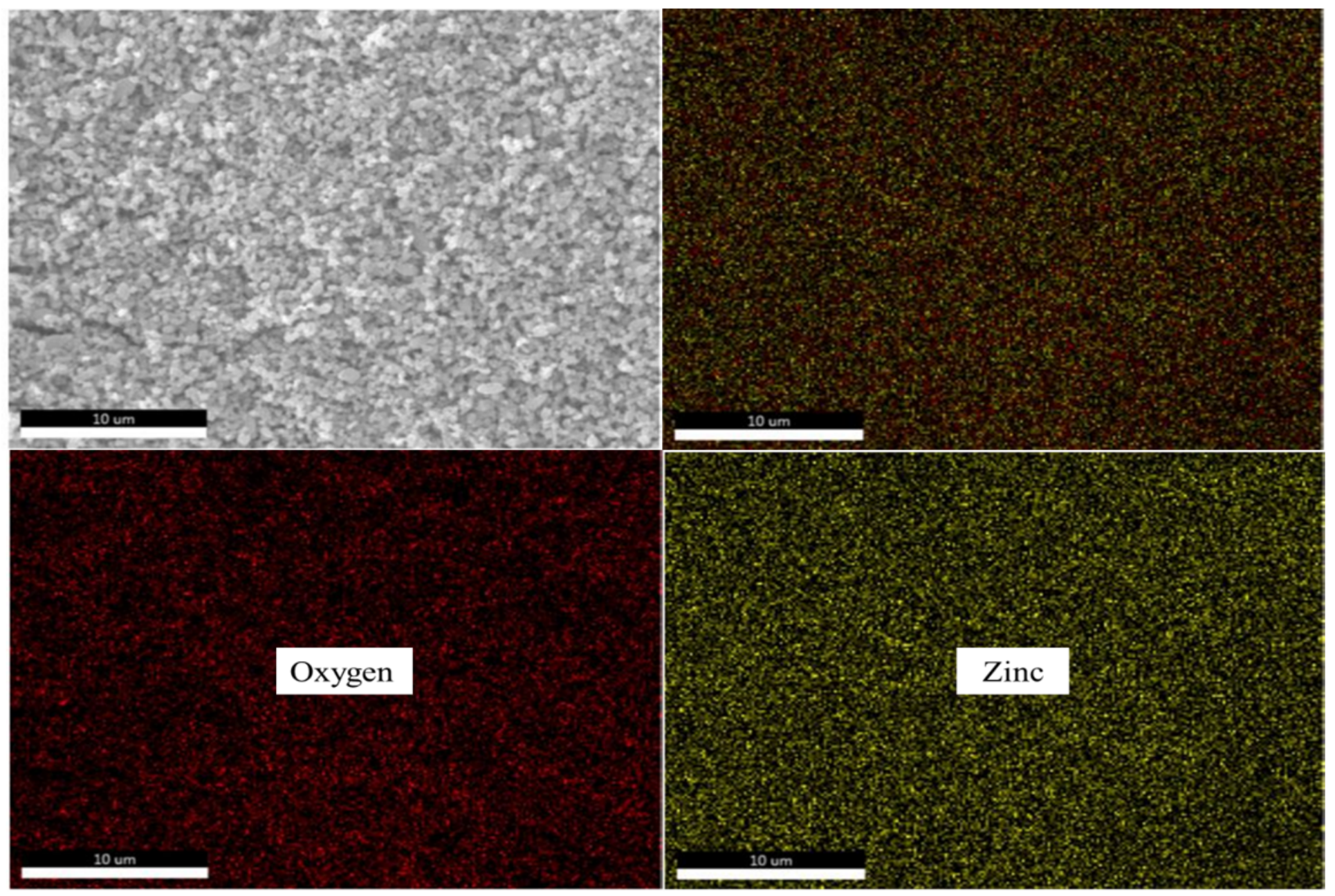

Figure 8

EDX mapping of ZnO 


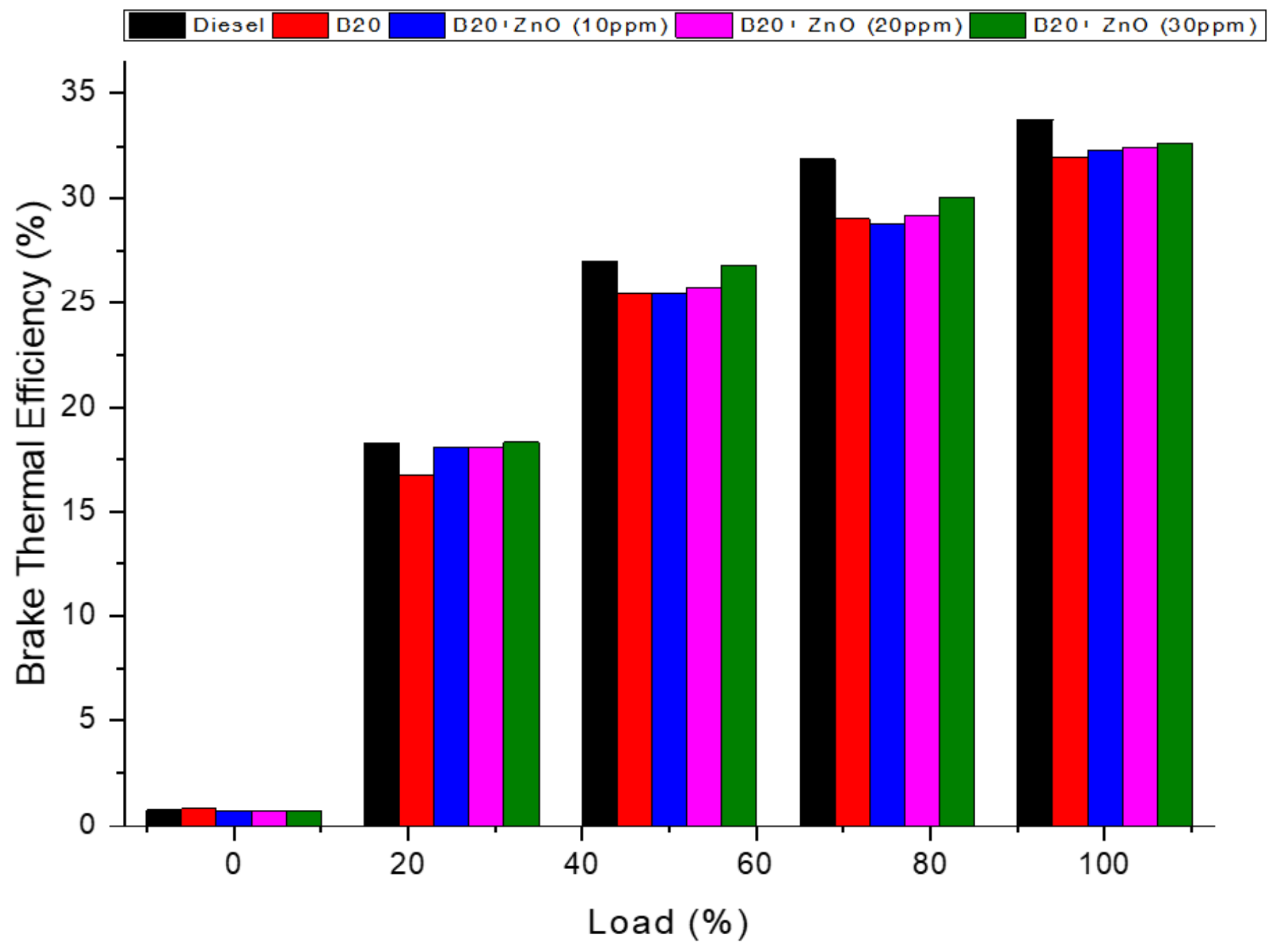

Figure 9

Brake Thermal Efficiency 


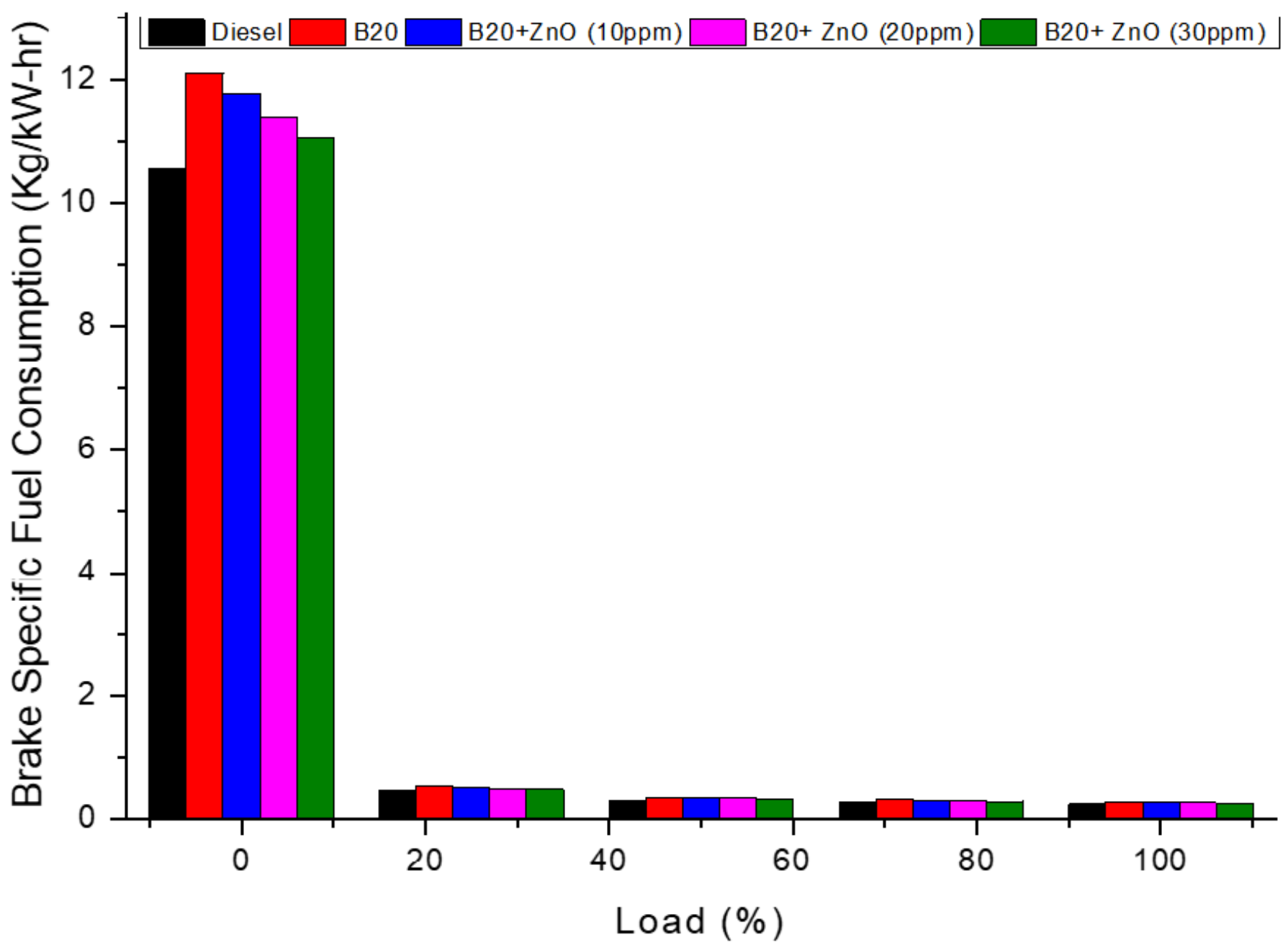

Figure 10

Brake Specific Fuel Consumption 


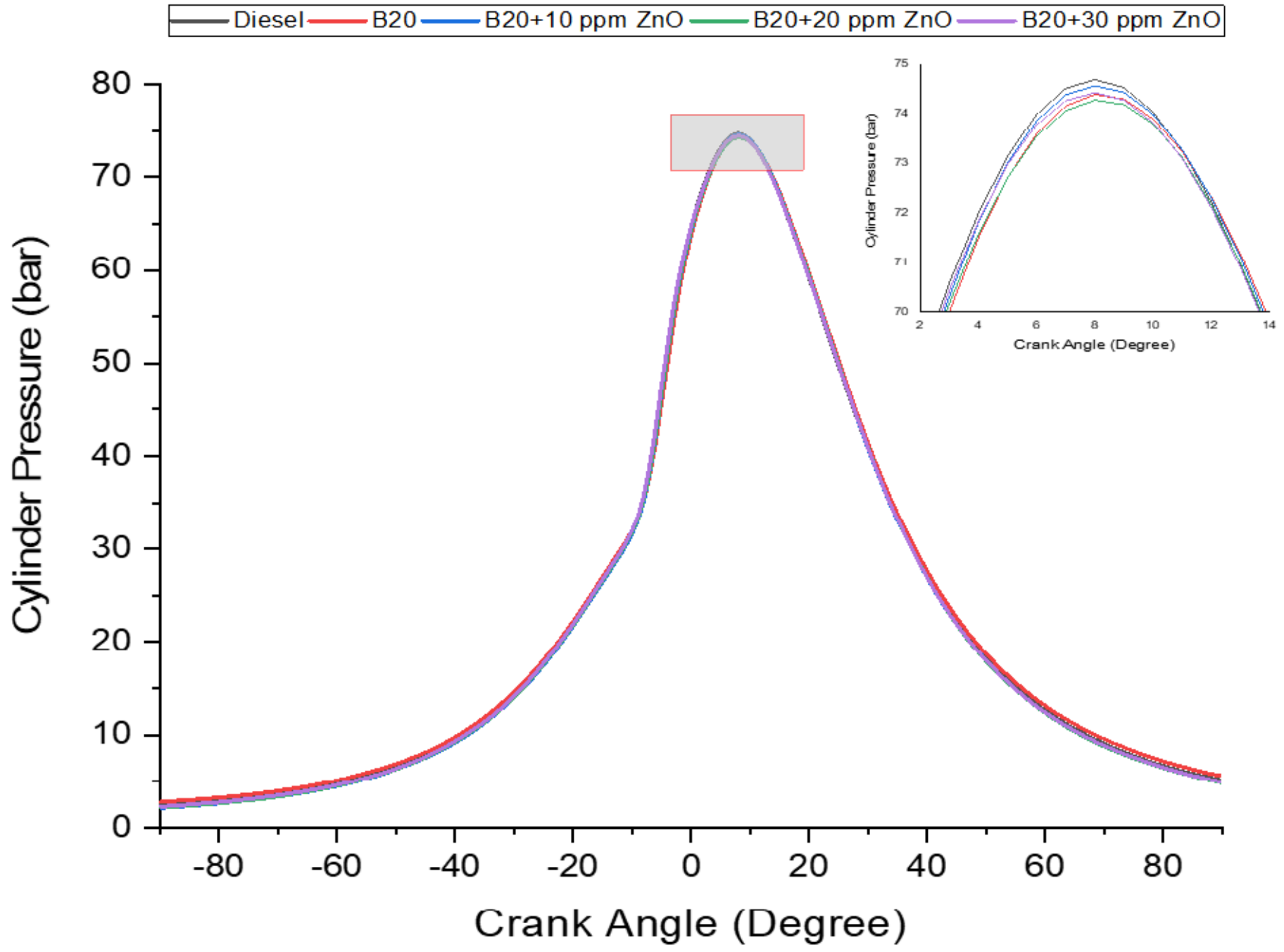

Figure 11

Brake Specific Fuel Consumption 


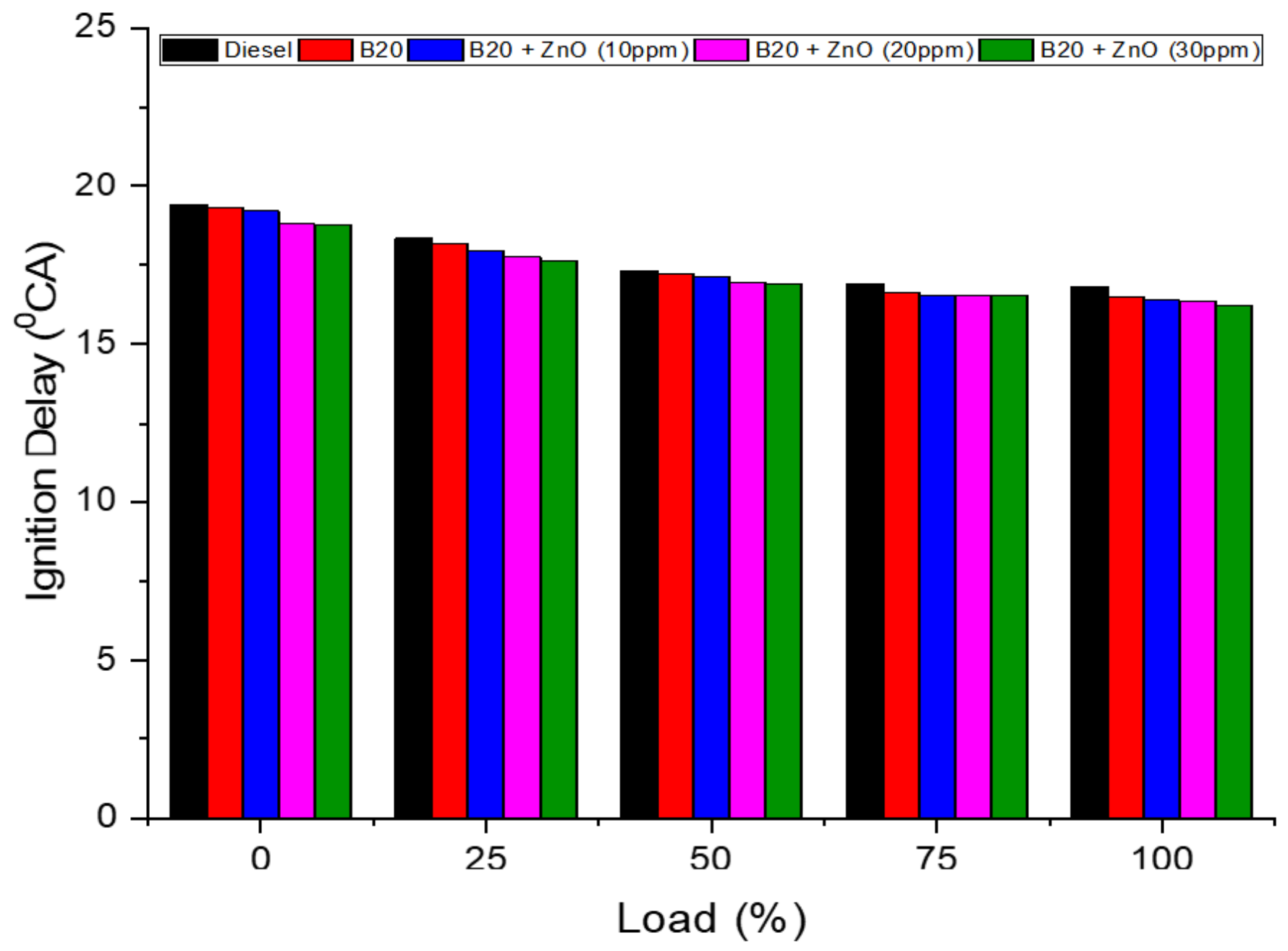

Figure 12

Ignition Delay 


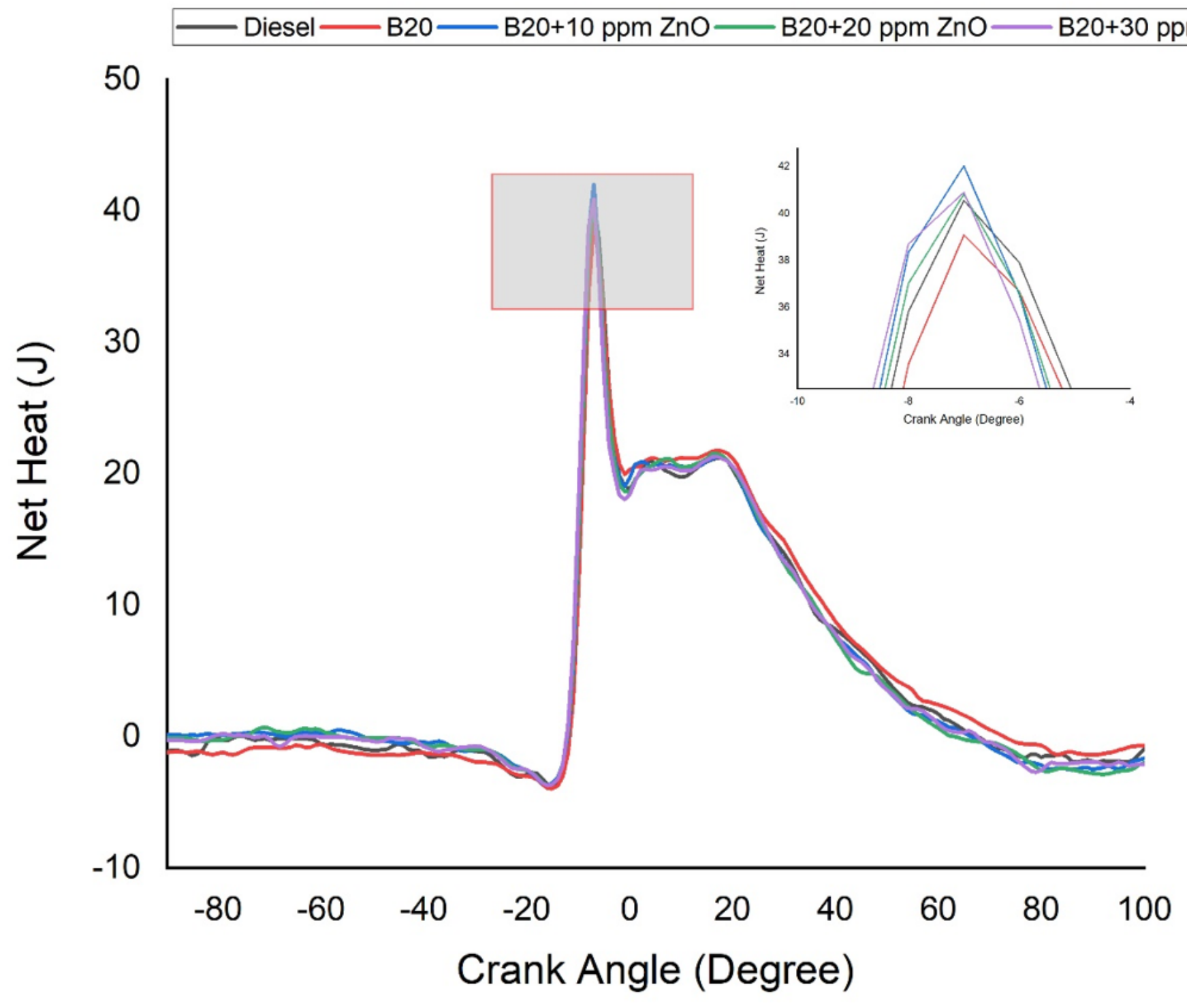

Figure 13

Net Heat Release Rate 


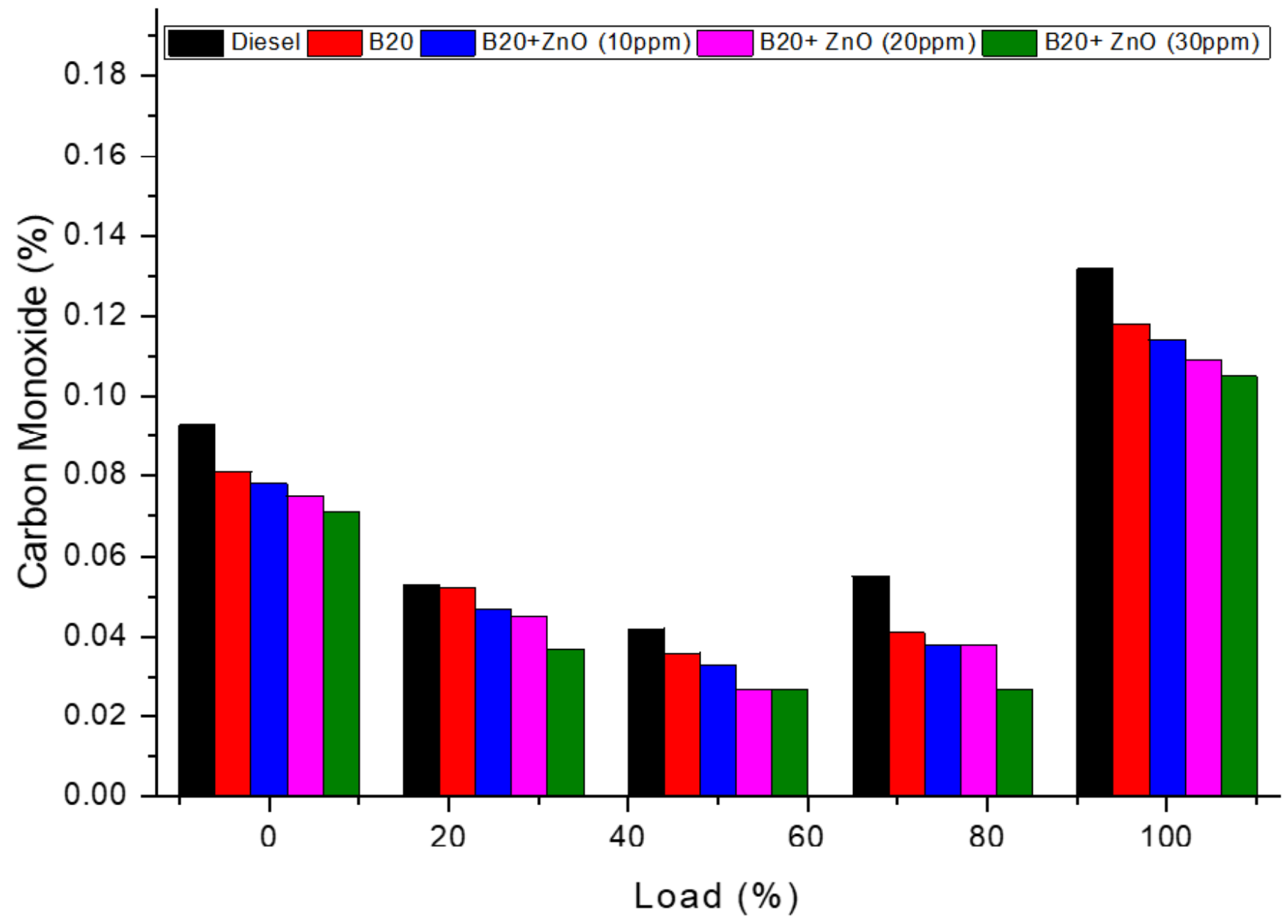

Figure 14

CO Emission 


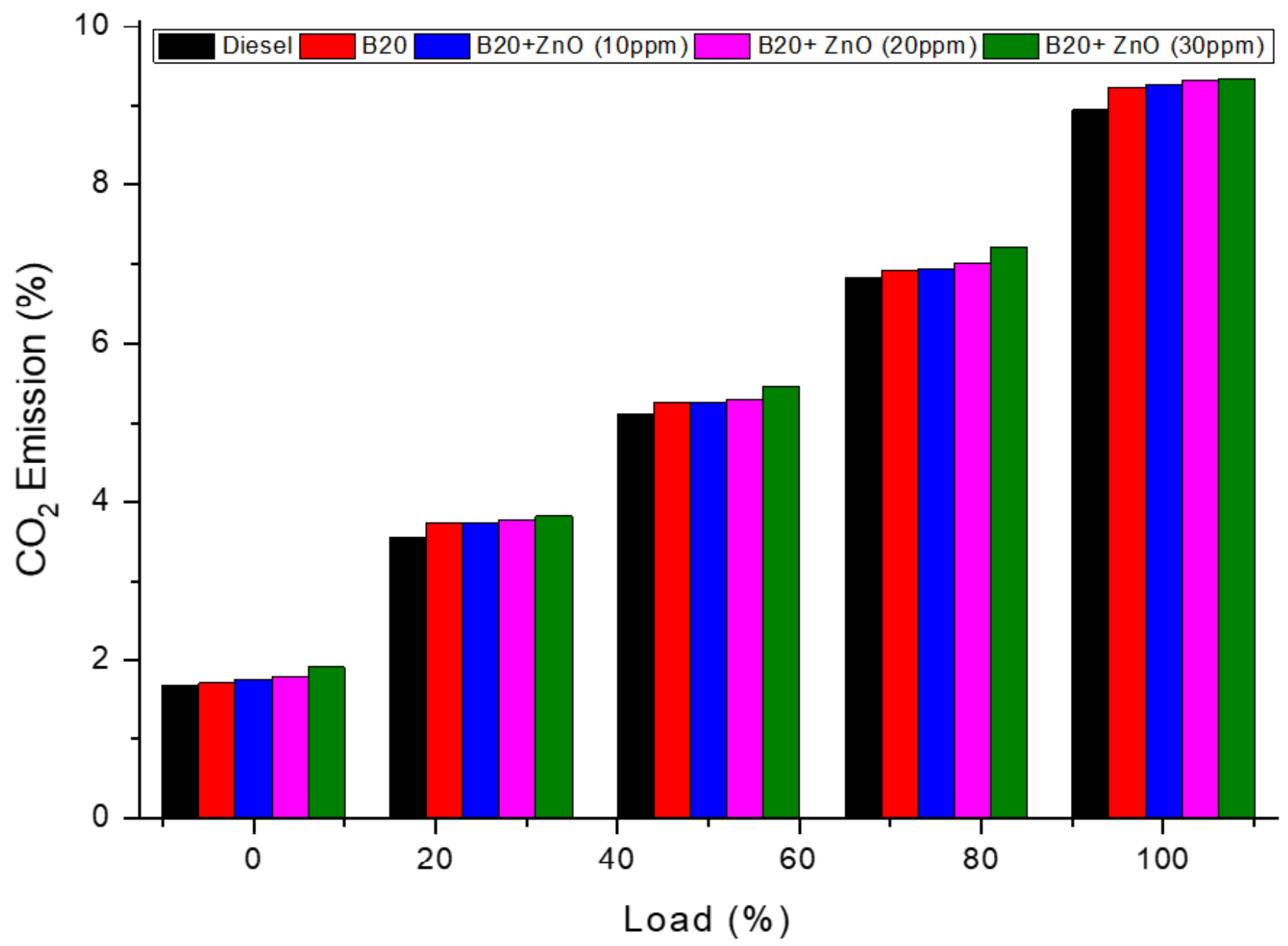

Figure 15

CO2 Emission 


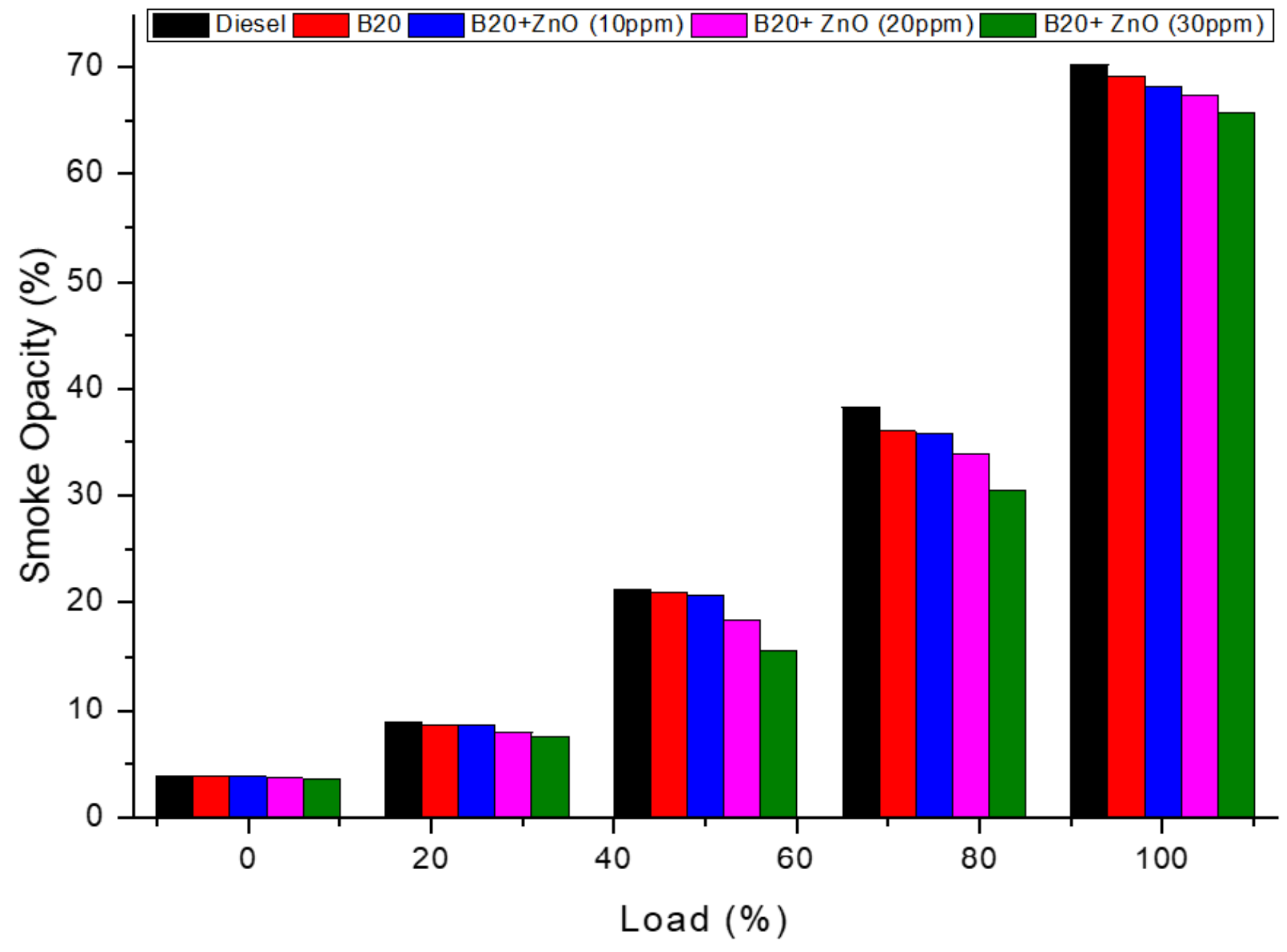

Figure 16

Smoke Opacity 


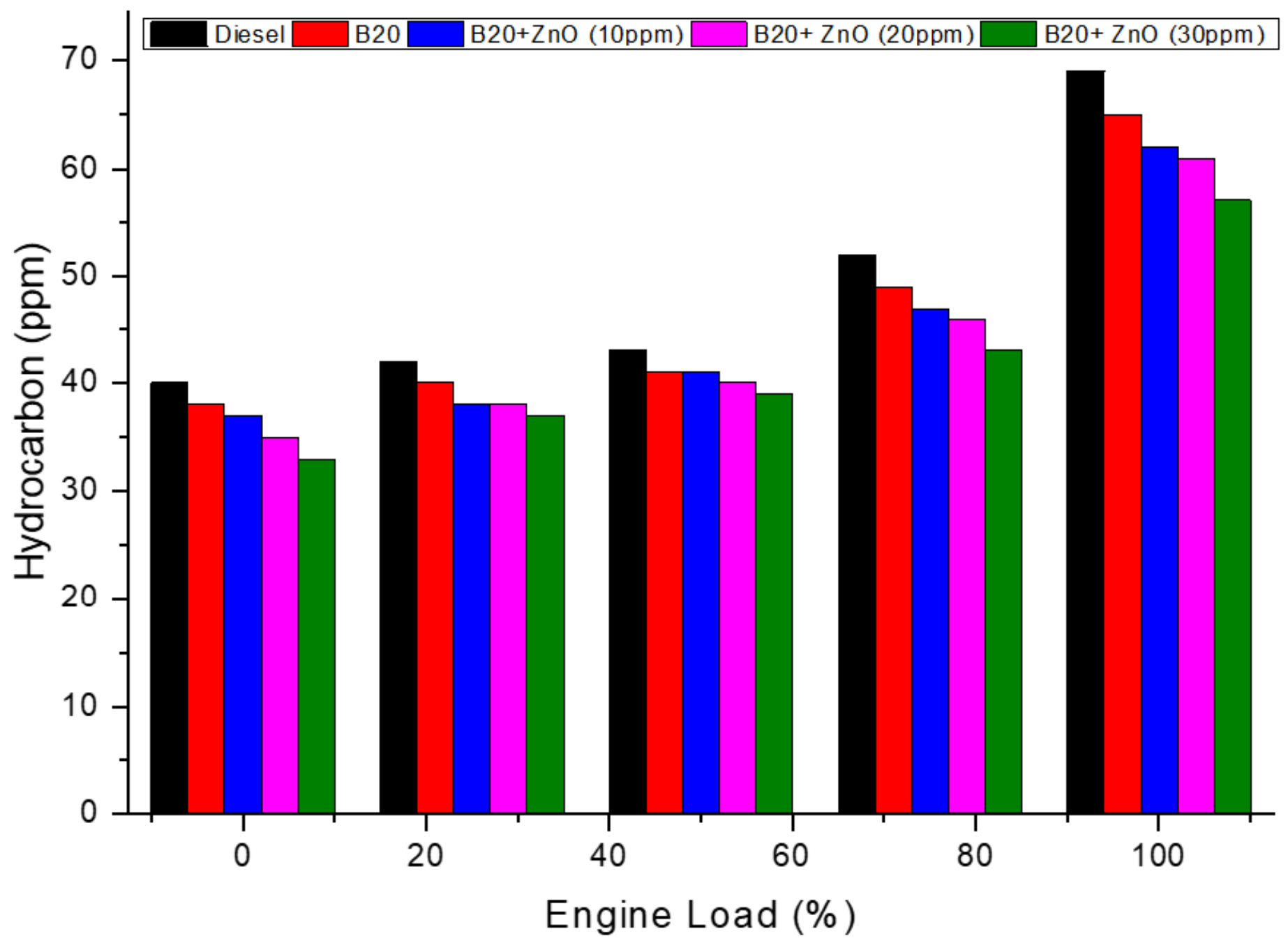

Figure 17

Hydrocarbon 


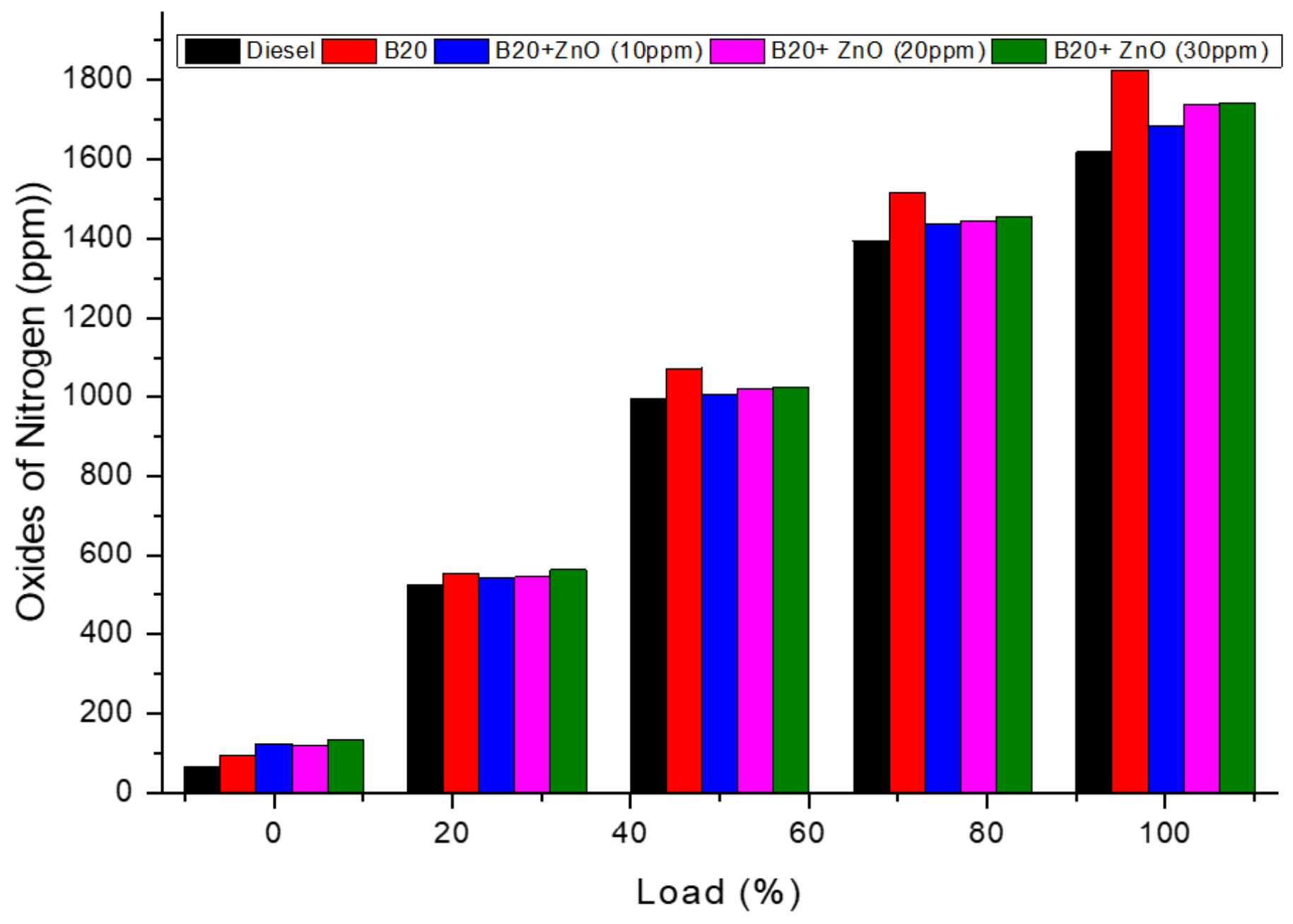

Figure 18

NOx Emission 